\title{
Hydrologic and biogeochemical controls on the spatial and temporal patterns of nitrogen and phosphorus in the Kuparuk River, arctic Alaska
}

\author{
James P. McNamara, ${ }^{1 *}$ Douglas L. Kane, ${ }^{2}$ John E. Hobbie ${ }^{3}$ and George W. Kling ${ }^{4}$ \\ ${ }^{1}$ Department of Geosciences, Boise State University, Boise, ID 83725, USA \\ ${ }^{2}$ Institute of Northern Engineering, University of Alaska Fairbanks, Fairbanks, AK, USA \\ ${ }^{3}$ The Ecosystems Center, Marine Biological Laboratory, Woods Hole, MA, USA \\ ${ }^{4}$ Department of Ecology and Evolutionary Biology, University of Michigan, Ann Arbor, MI, USA
}

\begin{abstract}
:
Nitrogen $(\mathrm{N})$ and phosphorus $(\mathrm{P})$ dynamics in the Kuparuk River in arctic Alaska were characterized in a 3-year study using routine samples near the mouth of the river at the Arctic Ocean, synoptic whole-river surveys, and temporally intense sampling during storms in three headwater basins. The Lower Kuparuk River has low nitrate concentrations (mean $\left[\mathrm{NO}_{3}^{-}-\mathrm{N}\right]=17 \mu \mathrm{g}$ $1^{-1} \pm 1.6 \mathrm{SE}$ ) and dissolved inorganic $\mathrm{N}$ (DIN, mean $[\mathrm{N}]=31 \mu \mathrm{g} \mathrm{l^{-1 }} \pm 1.2 \mathrm{SE}$ ) compared with rivers in more temperate environments. Organic forms constituted on average $90 \%$ of the $\mathrm{N}$ exported to the Arctic Ocean, and high ratios of dissolved organic $\mathrm{N}(\mathrm{DON})$ to total dissolved N (TDN) concentrations (mean 0.92) likely result from waterlogged soils formed by reduced infiltration due to permafrost and low hydrologic gradients. Annual export of TDN, DON, and particulate N averaged $52 \mathrm{~kg} \mathrm{~km}^{-2}, 48 \mathrm{~kg} \mathrm{~km}^{-2}$, and $4.1 \mathrm{~kg} \mathrm{~km}^{-2}$ respectively. During snowmelt, the high volume of runoff typically results in the highest nutrient loads of the year, although high discharge during summer storms can result in substantial nutrient loading over short periods of time. Differences in seasonal flow regime (snowmelt versus rain) and storm-driven variation in discharge appear to be more important for determining nutrient concentrations than is the spatial variation in processes along the transect from headwaters towards the ocean. Both the temporal variation in nitrate: DIN ratios of headwater streams and the spatial variation in nitrate: DIN between larger sub-basins and smaller headwater catchments is likely controlled by shifts in nitrification and soil anoxia. Copyright (C) 2008 John Wiley \& Sons, Ltd.
\end{abstract}

KEY WORDS nitrogen; phosphorus; catchment; Arctic; river; export; loading; flushing; Kuparuk River

Received 11 September 2006; Accepted 18 September 2007

\section{INTRODUCTION}

Coupled hydrologic and biogeochemical processes control the concentrations and fluxes of nutrients in riverine systems, which impact primary production in aquatic ecosystems and the delivery of nutrients to the world's oceans. Although temperate and tropical environments have received considerable attention, there are relatively few data on riverine nutrient concentrations and fluxes in arctic regions; see Dittmar and Katner (2003). This is of particular concern because, in the advent of global climate change, arctic regions are expected to undergo the most pronounced shifts in climate compared with other regions of the world (Houghton et al., 2001). Environmental changes have already taken place in the Arctic, including significant air temperature increases over the Arctic Ocean and thinning of the arctic sea ice cover (Serreze et al., 2000; Hinzman et al., 2005). Because arctic ecosystem processes are highly temperature sensitive, understanding the controls that arctic conditions have on nutrient transport is essential to understanding potential changes to this sensitive region.

\footnotetext{
* Correspondence to: James P. McNamara, Department of Geosciences, Boise State University, Boise, ID 83725, USA.

E-mail: jmcnamar@boisestate.edu
}

Nutrient studies in large rivers have focused primarily on reporting loads (Lewis, 1991; Lewis et al., 1999). Meybeck (1982) suggested that arctic rivers have low nutrient concentrations and loads, but that study included only one small arctic stream. Lewis (2002) reported that runoff is the dominant control on nutrient flux from minimally disturbed catchments; however, no arctic rivers were included in that study. Recent investigations in small catchments in the European Arctic (Kashulina et al., 1998) and in northern Alaska reported that nitrogen $(\mathrm{N})$ and phosphorus $(\mathrm{P})$ concentrations in lakes and headwater streams in the region are low (Kling et al., 1992, 2000; Peterson et al., 1992). Further, dissolved organic matter concentrations in arctic rivers are among the highest in the world, and inorganic nutrient concentrations are among the lowest (Dittmar and Kattner, 2003; Dittmar, 2004).

Two important aspects of arctic river chemistry have received little study: first, the specific mechanisms controlling nutrient movement from terrestrial to aquatic systems in arctic watersheds are poorly known (e.g. Stieglitz et al., 2003); second, it is unclear whether these controls on nutrient chemistry operate differently between headwater streams and large rivers. In this paper we address these two aspects through a study of the spatial and 
temporal patterns of dissolved and particulate fluxes of $\mathrm{N}$ and $\mathrm{P}$ for the Kuparuk River in arctic Alaska.

In terms of controlling mechanisms, hydrologic processes influence the origin, transport, and fate of nutrients in river systems through influences on the reduction/oxidation state of soils, the delivery of solutes from terrestrial to aquatic systems, and in-stream biogeochemical cycling. Hydrologic literature for the temperate zone is rich with studies describing how nutrients move from terrestrial to aquatic systems in headwater catchments, with a particular emphasis on the response of nutrients to rain and snowmelt. For example, the hydrologic flushing mechanism is often invoked to explain commonly observed asynchronous hydrographs and chemographs during storms. This hypothesis requires that nutrients accumulate in near-surface soils due to biogeochemical processes during interstorm periods, then a rising water table during storms incorporates those nutrients and flushes them to a stream (Creed et al., 1996; Burns et al., 1998; Burns, 2005). Because many of the catchment characteristics that facilitate hydrologic flushing are modified by permafrost, extended snow and ice seasons, or high abundances of organic soils (e.g. Giblin et al., 1991), this accumulation and flushing may operate differently in arctic regions. For example, McNamara et al. (1997) showed that hillslope hydrologic pathways change as soils thaw; the most important changes occur between snowmelt and the first summer rainstorm.

The goal of this paper is to increase the understanding of coupled hydrology and biogeochemistry in arctic river systems. Three specific issues are examined concerning the relationships between hydrology and nutrients ( $\mathrm{N}$ and $\mathrm{P})$. First, how do nutrient concentrations and fluxes in the Kuparuk River, as a representative of arctic catchments, compare with those in other regions? Second, what processes control the spatial patterns of concentrations and fluxes within the catchment from its headwaters to its mouth? Third, what mechanisms are most important in affecting the temporal changes in concentrations and fluxes during storms and at seasonal time-scales?

\section{STUDY AREA AND HYDROLOGIC SETTING}

From its source in the northern foothills of the Brooks Range, the Kuparuk River flows northward across the Arctic Coastal Plain to the Arctic Ocean near Prudhoe Bay, Alaska (Figure 1). The region is underlain by continuous permafrost and is covered with snow for 7 to 9 months a year. Permafrost thickness ranges from around $250 \mathrm{~m}$ near the foothills to over $600 \mathrm{~m}$ near the coast (Osterkamp and Payne, 1981). Soils typically thaw to maximum depths of $40-50 \mathrm{~cm}$, called the active layer, but can thaw to over $100 \mathrm{~cm}$ in well-drained sites (Hinzman et al., 1991). The flow season typically begins in mid May in the headwaters and late May to early June near the coast, although the window for snowmelt can be 6 weeks. Freeze-up typically begins in mid September to mid October. Some $50-80 \%$ of the annual streamflow at the Lower Kuparuk River occurs during snowmelt (McNamara et al., 1998; Déry et al., 2005). Approximately $40 \%$ of the catchment is relatively flat coastal plain. Because of the low hydraulic gradient (Rovansek et al., 1996; Mendez et al., 1998), the dominant export of water during the summer from small basins close to the coast is by evaporation; there is little overland and channel flow.

The US Geological Survey gauges the Kuparuk River approximately $13 \mathrm{~km}$ upstream from the Arctic Ocean at Prudhoe Bay (Station 1 in Figure 1). Below this point the river is distributed into several channels. Above this point the river has occasional braided sections but is predominately a meandering gravel-bed river. The river substrate is well sorted, with a mean grain size of approximately $20 \mathrm{~cm}$ (Best, 2002) and the bankfull channel width is approximately $195 \mathrm{~m}$ (Best et al., 2005).

The Upper Kuparuk River basin occupies $142 \mathrm{~km}^{2}$, with a basin length of $16 \mathrm{~km}$ and a channel length of $25 \mathrm{~km}$ where the Dalton Highway intersects the river (Figure 1). The elevation ranges between 698 and

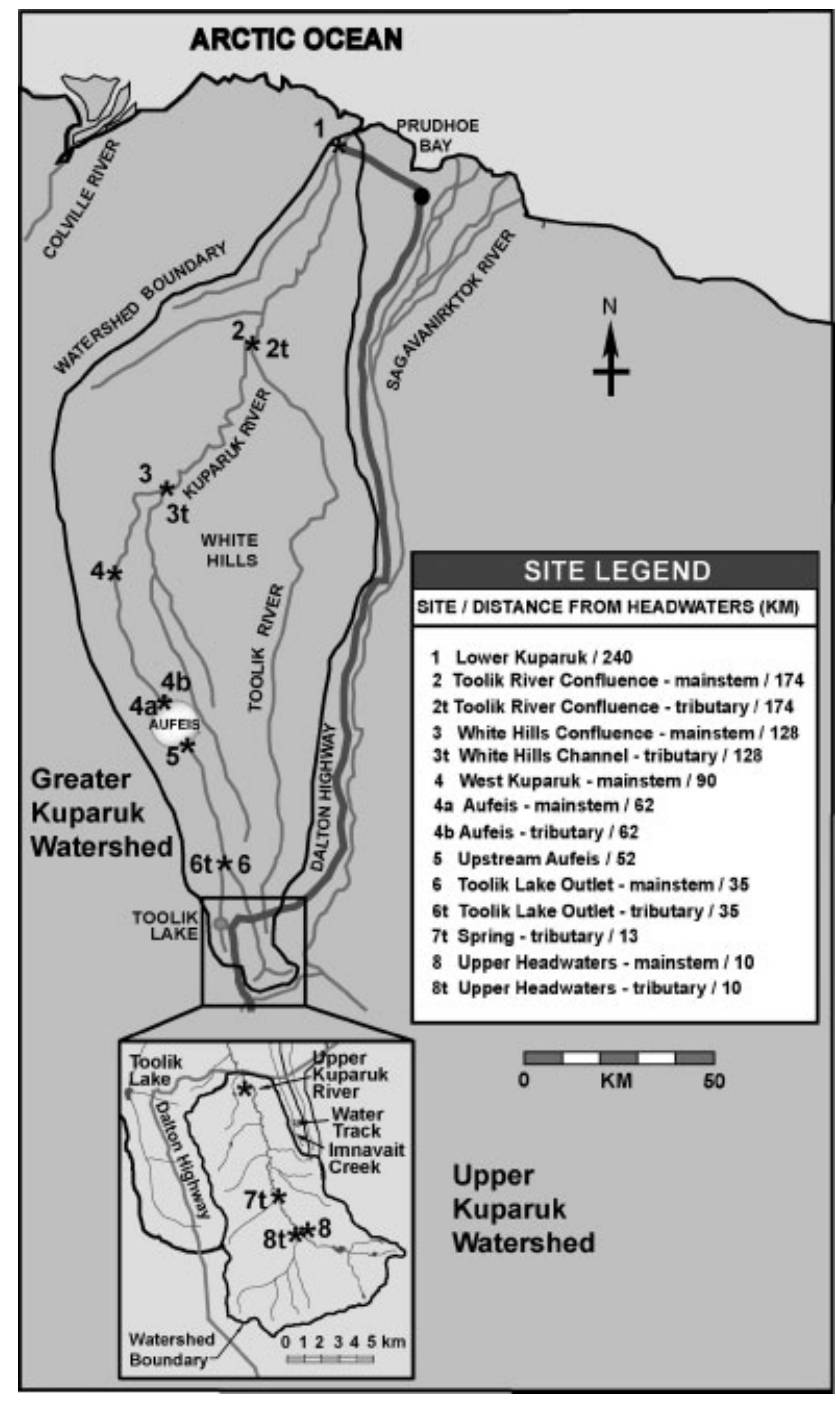

Figure 1. Location map of the sampling sites in the Kuparuk River and its tributaries on the North Slope of Alaska. The Lower Kuparuk River (site \#1) is located at $70^{\circ} 19 \cdot 62^{\prime} \mathrm{N}, 149^{\circ} 00 \cdot 08^{\prime} \mathrm{W}$ 
$1464 \mathrm{~m}$, with an average of $967 \mathrm{~m}$. Vegetation consists of alpine communities at higher elevations and moist tundra communities, predominantly tussock tundra, at lower elevations. Dwarf willows and birches up to $1 \mathrm{~m}$ in height occupy portions of the banks and water tracks on hillslopes (Walker et al., 1989). The river substrate is poorly sorted gravel, with a mean grain size of approximately $70 \mathrm{~cm}$ with numerous large boulders. The bankfull width is approximately $20 \mathrm{~m}$ (Oatley, 2002).

Imnavait Creek drains $2.2 \mathrm{~km}^{2}$ in a north-northwesttrending valley that was formed during the Sagavanirktok glaciation (Middle Pleistocene) (Hamilton, 1986). The elevation of the basin ranges between $844 \mathrm{~m}$ (at the gauging weir) and $960 \mathrm{~m}$, with an average of $904 \mathrm{~m}$. The dominant vegetation in the Imnavait basin is tussock tundra (Eriophorum spp.) covering the hillslopes, and a mixture of birch, willow, and sedges in the water tracks (Walker et al., 1989). An organic layer typically $\sim 10 \mathrm{~cm}$ thick, but up to $50 \mathrm{~cm}$ thick in the valley bottom, overlies mineral soil and glacial till (Hinzman et al., 1991). The creek is essentially a chain of small ponds, called beads, up to $5 \mathrm{~m}$ across that formed where the stream eroded into and melted massive ground-ice deposits. The stream bottom is mainly contained within the organic layer and rarely cuts through to mineral soil. Imnavait Creek flows another $12 \mathrm{~km}$ beyond our stream gauging and monitoring station to its confluence with the Kuparuk River.

Numerous water tracks, generally spaced tens of metres apart, drain the hillslopes in Imnavait Creek. A water track is essentially a linear channel that flows directly down a slope draining an enhanced soil moisture zone, and is best detected by a change in vegetation from the surrounding hillslope (McNamara et al., 1999). The smallest scale studied was a hillslope water track that drains $0.026 \mathrm{~km}^{2}$ on a west-facing slope in the Imnavait Creek headwater basin (Figure 1). The water track ends in a peat-covered valley bottom through which water travels to the stream as diffuse subsurface flow through the active layer.

The total precipitation in each year of the study was similar to or slightly below the long-term average (McNamara et al., 1998; Kane et al., 2004). The annual precipitation in Imnavait Creek in 1994, 1995, and 1996 was $351 \mathrm{~mm}, 351 \mathrm{~mm}$, and $321 \mathrm{~mm}$ respectively, and the ratio of precipitation that fell as snow was 0.58 , 0.39 , and 0.55 respectively. Despite the relatively similar amounts of precipitation in all three years, the peak snowmelt flow at the Lower Kuparuk River in 1996 was approximately twice as high as the previous 2 years (Figure 2). The annual flows during 1994, 1995, and 1996 were statistically similar to a 20 -year record for the Kuparuk River (McNamara, 2000).

Permafrost and frozen soil strongly influence hydrologic processes in the Kuparuk River basin. For example, streamflow during snowmelt is composed of essentially all new meltwater because subsurface storage is minimal due to the frozen active layer (McNamara et al.,
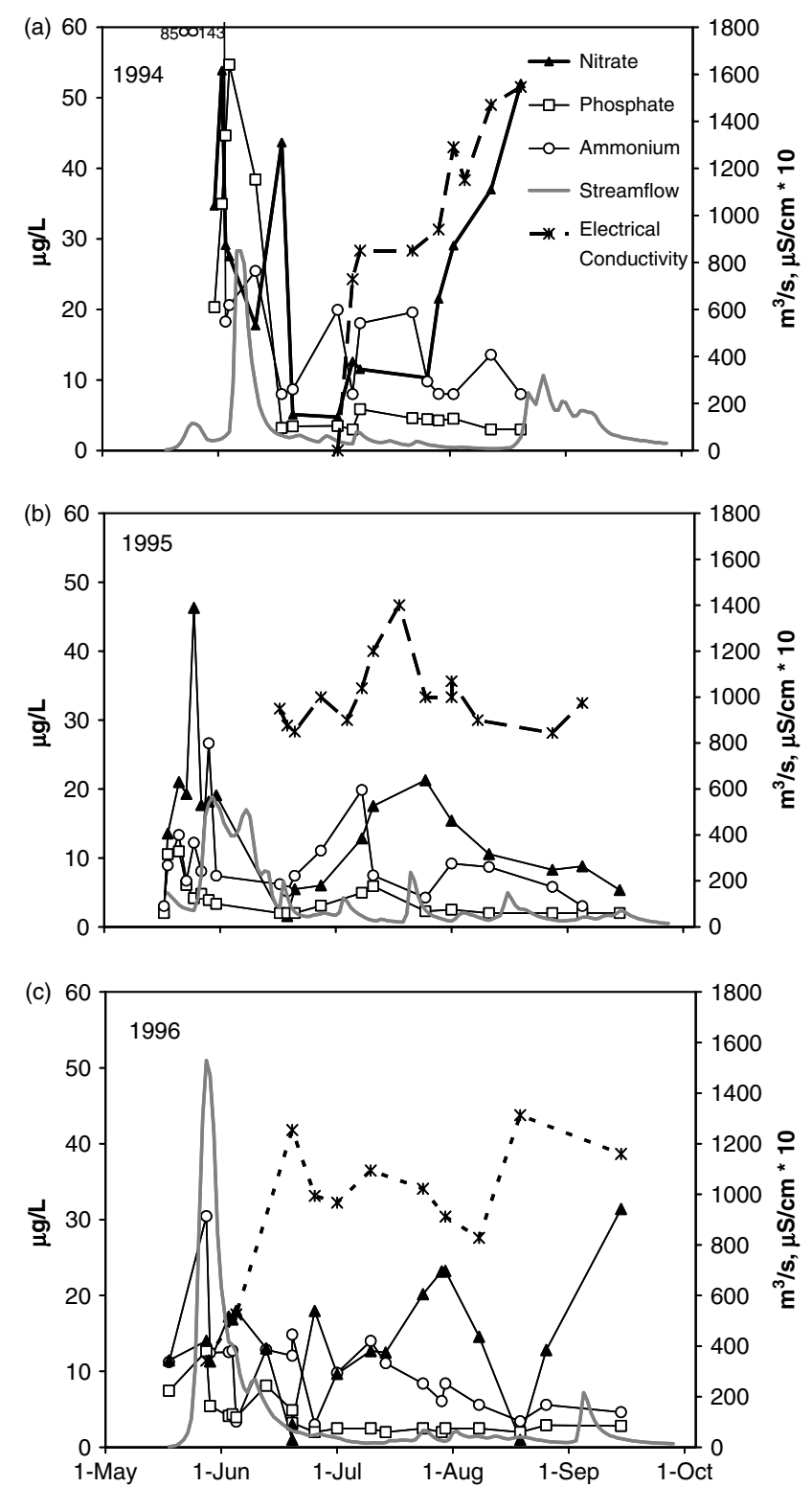

Figure 2. Dissolved nutrient concentrations (left axis), electrical conductivity (right axis), and streamflow (right axis) at the Lower Kuparuk River in (a) 1994, (b) 1995, and (c) 1996. Error bars are not shown for clarity

1997). Conversely, streamflow generated by the first summer rainstorm after a period of thawing is composed of over $50 \%$ pre-event water (water that was in the catchment prior to the storm). In some years, the pre-event water contributions to streamflow continue to increase through the summer (McNamara et al., 1997). Likewise, the ratio of streamflow to precipitation during summer storms tends to decrease through the summer as subsurface storage capacity increases (McNamara et al., 1998). Both of these summer trends can be masked by precipitation patterns (McNamara et al., 1997, 1998), but the change from event water dominating streamflow during snowmelt to pre-event water dominating the first summer storm occurs each year. McNamara et al. (1997) speculated that this transition has important implications for nutrient transport to streams. 


\section{METHODS}

Water samples were collected from the beginning of snowmelt to near freeze-up of the river from 1994 to 1996 using three sampling schemes. Weekly grab samples were collected near the mouth of the Kuparuk River at the farthest downstream site that is accessible by road (Station 1 in Figure 1). Synoptic down-river sampling surveys were performed by helicopter three to six times a year at eight stations in the mainstream of the Kuparuk River and in six tributaries (Figure 1). Temporally intense sampling was performed during storms in three headwater catchments of the upper Kuparuk basin with ISCO automatic water samplers programmed to collect 11 of water every $3 \mathrm{~h}$ throughout the summer. When storms occurred, subsamples were collected from each 1-1 bottle and processed similarly to the grab samples. Snowpack meltwater was collected in a high-density polyethylene tray that was inserted at the base of the snowpack before the initiation of melt. Samples were filtered into plastic bottles (Nalgene, HDPE, Rochester, NY) using a rinsed syringe and filter assembly (Gelman, Ann Arbor, MI) with a pre-combusted Whatman $\mathrm{GF} / \mathrm{F}$ filter. The $\mathrm{GF} / \mathrm{F}$ filters were dried and then frozen until analysis for particulate $\mathrm{N}(\mathrm{PN})$, particulate $\mathrm{P}(\mathrm{PP})$, and particulate carbon (PC). PN and PP samples were only collected during the synoptic surveys, and total dissolved N (TDN) and total dissolved P (TDP) samples were not collected during storms in the headwater catchments. Samples for nitrate $\left(\mathrm{NO}_{3}^{-}-\mathrm{N}\right)$, ammonium $\left(\mathrm{NH}_{4}-\mathrm{N}\right)$, and phosphate $\left(\mathrm{PO}_{4}-\mathrm{P}\right.$, as soluble reactive orthophosphate) were stored on ice and analysed at the Toolik Field Station within $24 \mathrm{~h}$ of collection. TDN and TDP samples were acidified to $\mathrm{pH} \sim 2-3$ and stored in a refrigerator until later analysis at the Marine Biological Laboratory or the University of Michigan.

Nitrate, phosphate, and ammonium were analysed simultaneously using an Alpkem automatic analyser with model 510 detectors (Alpkem Corporation, Clackamas Oregon). Standard solutions for each nutrient were prepared daily from stock solutions (Hach Company, Ames, IA). The nitrate-nitrite cadmium reduction method (Alpkem Doc. no. 000630) was used to determine nitrate concentrations. Note that this test detects both nitrate and nitrite $\left(\mathrm{NO}_{2}^{-}\right)$, although nitrate dominates in oxygenated waters; the sum of nitrate and $\mathrm{NO}_{2}^{-}$are reported here simply as nitrate. Soluble reactive phosphate was analyzed with a molybdenum-ascorbic acid method (Alpkem Doc. no. 000 629). Ammonium was analysed using a phenol-hypochlorite method (Alpkem Doc. no. 000674) without a gas diffusion membrane. Dissolved inorganic $\mathrm{N}$ (DIN) is the sum of nitrate and ammonium.

All standards were run in duplicate. A blank was run every five samples and a duplicate sample and a standard were run every 10 samples to check accuracy and precision. The limit of detection was determined for each run by taking the standard deviation of all standards of the same concentration that were run on that day. In 1994, the average limits of detection for $\mathrm{NH}_{4}-\mathrm{N}, \mathrm{PO}_{4}-\mathrm{P}$, and
$\mathrm{NO}_{3}^{-}-\mathrm{N}$ were $8 \mu \mathrm{g} \mathrm{l}^{-1}, 3 \mu \mathrm{g} \mathrm{l}^{-1}$, and $4 \mu \mathrm{g} \mathrm{l^{-1 }}$ respectively; in 1995 and 1996, the limits improved to $3 \mu \mathrm{g} 1^{-1}$, $2 \mu \mathrm{g}^{-1}$, and $1 \mu \mathrm{g}^{-1}$ respectively. On some occasions, a series of additions of a known amount of standard to samples were analysed in order to determine for each chemical test the potential matrix effect in our samples. These analyses indicated that sample values were often at or below our routine level of detection (especially for ammonium and phosphate) and that the matrix effect increased the apparent sample concentration. Although these analyses were performed too infrequently to make any bulk corrections to our sample values, we note that our reported concentrations are probably maximum values.

TDN and TDP were measured as nitrate and soluble reactive phosphate on a Technicon autoanalyser after a potassium persulphate digestion (Langner and Hendrix, 1982; Kling et al., 2000). Dissolved organic N (DON) was estimated by subtracting the ammonium and nitrate concentrations from the TDN concentration of an individual water sample. Similarly, dissolved organic P (DOP) was estimated by subtracting the phosphate concentration from the TDP concentration of an individual water sample; if this value was negative it was set to zero for calculations. PN was determined on a Perkin-Elmer 2400 elemental analyser against an acetanilide standard. PP was measured using an $\mathrm{HCl}$ digestion followed by analysis of phosphate on an autoanalyser. Limits of detection on particulate fractions were $\sim 2 \mu \mathrm{g}^{-1}$ for both $\mathrm{N}$ and P. Alkalinity was measured using potentiometric titrations with $0.05 \mathrm{M} \mathrm{H}_{2} \mathrm{SO}_{4}$ and analysed with the method of Gran (Stumm and Morgan, 1981).

Water temperature, $\mathrm{pH}$, and electrical conductivity (EC) were measured in the field. EC was also monitored hourly in the Kuparuk River and Upper Kuparuk River using Campbell Scientific instrumentation. The US Geological Survey in Fairbanks, Alaska, provided discharge data at the Lower Kuparuk River. Researchers from the University of Alaska Fairbanks gauged the Water Track, Imnavait Creek, and Upper Kuparuk River.

When sample values were below the detection limit we used the detection limit for that sample for calculating average concentrations and fluxes according to Gilliom and Helsel (1986). Annual fluxes of individual chemical species at the Lower Kuparuk River were calculated by summing the daily fluxes and normalizing by drainage area to get annual export in kilograms per square kilometre. Daily fluxes were calculated by multiplying the daily streamflow rate by either the sample concentration on that day, or the average of the concentration of two samples on dates bounding the daily flow. In headwater basins where samples were collected more frequently, instantaneous fluxes were calculated by multiplying concentrations by flow rates at the time of sample collection. These instantaneous fluxes were then integrated over the duration of storms to get total storm flux, or over the entire season to obtain total annual flux. Error on our 
flux estimates $E_{\mathrm{L}}$ was determined using

$$
E_{\mathrm{L}}=\sqrt{E_{\mathrm{D}}^{2}+E_{\mathrm{C}}^{2}}
$$

where $E_{\mathrm{D}}$ is the error in discharge measurements and $E_{\mathrm{C}}$ is the error in the measurement of the species of interest. The US Geological Survey reports that errors on discharge measurements range from 2 to $20 \%$ (Sauer and Meyer, 1992). We used the conservative error of $20 \%$. Concentration errors were calculated as the ratio of the detection limit over the measurement. Average $\mathrm{pH}$ was determined from average $\mathrm{H}^{+}$concentrations; standard deviation of $\mathrm{pH}$ was calculated using untransformed $\mathrm{pH}$ values.

\section{RESULTS}

Lower Kuparuk River: average concentrations, fluxes and temporal trends

The average concentration of TDN at the Lower Kuparuk River (Station 1 in Table I) was $[\mathrm{N}]=296 \mu \mathrm{g}^{-1}$; only $\sim 10 \%$ was as DIN $([\mathrm{N}]=$ $\left.31 \mu \mathrm{g}^{-1}\right)$. DIN was nearly equally split between nitrate $\left([\mathrm{N}]=17 \mu \mathrm{g}^{-1}\right)$ and ammonium $\left(\mathrm{N}=15 \mu \mathrm{g} \mathrm{l}^{-1}\right)$. Analyses of PN were limited. In those samples, PN was a minor component of the total $\mathrm{N}$ (TN) with values less than $10 \%$ of TN. The average concentration of TDP was $[\mathrm{P}]=5.5 \mu \mathrm{g}^{-1}, 50 \%$ of which was DOP. Average $\mathrm{pH}$, conductivity, and alkalinity were $7.82,99.4 \mu \mathrm{S} \mathrm{cm}^{-1}$, and $1090 \mu$ eq $1^{-1}$ respectively.

The TDN flux ( $\mathrm{N}=52 \mathrm{~kg} \mathrm{~km}^{-2}$ year $\left.^{-1}\right)$ was approximately $88 \%$ organic $\left(\mathrm{N}=48 \mathrm{~kg} \mathrm{~km}^{-2}\right.$ year $\left.^{-1}\right)$ and DIN flux was $\mathrm{N}=5.0 \mathrm{~kg} \mathrm{~km}^{-2}$ year $^{-1}$ (Table II). The TDP flux $\left(\mathrm{P}=1.0 \mathrm{~kg} \mathrm{~km}^{-2}\right.$ year $\left.^{-1}\right)$ was approximately $74 \%$ organic $\left(\mathrm{P}=0.77 \mathrm{~kg} \mathrm{~km}^{-2}\right.$ year $\left.^{-1}\right)$. The average annual nitrate, ammonium, and phosphate fluxes were $\mathrm{N}=$ $3.0 \mathrm{~kg} \mathrm{~km}^{-2}, \mathrm{~N}=1.6 \mathrm{~kg} \mathrm{~km}^{-2}$, and $\mathrm{P}=1.3 \mathrm{~kg} \mathrm{~km}^{-2}$ respectively (Table II). The average annual $\mathrm{PN}$ and $\mathrm{PP}$ fluxes were $\mathrm{N}=4.1 \mathrm{~kg} \mathrm{~km}^{-2}$ and $\mathrm{P}=0.55 \mathrm{~kg} \mathrm{~km}^{-2}$ respectively.

An average of $67 \%$ of the annual water flow occurred during snowmelt each year, and the same period accounted for approximately $75 \%, 86 \%, 58 \%$, and $67 \%$ of the annual flux of ammonium, phosphate, nitrate and DIN respectively (Table III). Considering only the ascending limb of the snowmelt hydrograph, an average of $21 \%$ of the annual water flux and $36 \%, 45 \%, 24 \%$, and $33 \%$ of annual ammonium, phosphate, nitrate and DIN respectively occurred (data not shown). In comparison, the largest summer rainstorm produced only $20 \%$ of the annual streamflow. This value, however, is likely elevated due to the sustained high-flow period in September 1994, during which it was not possible to separate individual storms (Figure 2a). The same large storms accounted for approximately $8 \%, 6 \%, 29 \%$, and $20 \%$ of the annual ammonium, phosphate, nitrate and DIN respectively.

No statistically significant $(p=0.05)$ correlations were observed between any chemical species concentration and streamflow or date at the Lower Kuparuk River during snowmelt, summer (June-August), or annual time-scales. However, there were identifiable, qualitative trends. For example, each chemical species typically reached a peak concentration early during snowmelt prior to or near the peak flow and then decreased through the recession of the snowmelt streamflow (Figure $2 \mathrm{a}-\mathrm{c}$ ). This pattern is particularly clear for phosphate. In all years, phosphate decreased to the limit of detection soon after snowmelt and remained low for the remainder of the summer. Nitrate and ammonium also decreased to near detection limits following snowmelt each year, but increased to higher concentrations as summer progressed.

After snowmelt, nitrate tended to increase during extended low-flow periods, similar to EC (Figure 2). In 1994, this increase began in late July and continued through a low-flow period to the end of our monitoring season (Figure 2a). In 1995, this steady nitrate increase began in mid June and continued to late July, followed by a steady decrease during wetter conditions until the end of our monitoring season (Figure 2b). This pattern is not as clear in 1996, but concentrations increased from mid August to mid September (Figure 2c). The Pearson correlations between nitrate and conductivity in 1994 and 1995 were 0.82 and 0.67 respectively, and not significant in $1996(p=0 \cdot 05)$.

\section{Synoptic analysis}

Alkalinity and EC increased downstream in the mainstream of the Kuparuk River, but not in the tributary mouths (Figure 3c and f). Except for a spring near $13 \mathrm{~km}$ (mean $\mathrm{pH}$ 6.61), the $\mathrm{pH}$ was circum-neutral in the headwaters and tended to increase slightly towards the ocean. The tributaries were often quite different chemically than the mainstream at their confluence. For example, two tributaries, the Toolik River (confluence at Kuparuk River kilometre 174, Station 2t) and a small creek draining the Toolik Lake catchment with several lakes (confluence at $35 \mathrm{~km}$, Station 6t), consistently had almost double the alkalinity and EC than did the Kuparuk River.

In each year and at each station in the mainstream, DON was commonly around $90 \%$ of TDN (Table I). The downstream trends of average DON in the mainstream were similar each year, with a low concentration zone after Station $4 \mathrm{a}$ at river kilometre 62, and then a clear increase towards the ocean. Nitrate concentrations were anomalously (but consistently) high at Stations 4a (Figure 3b, mainstream between river kilometres 50 and 60 ) and $7 \mathrm{t}$ (Figure $3 \mathrm{e}$, a spring near the headwaters around river kilometre 13). In the tributaries, the DON contribution varied from $20 \%$ to $90 \%$ of TDN (Figure 3d). Similar to the mainstream, DON increased from Station $4 \mathrm{~b}$ towards the ocean. DIN was relatively important in tributaries of the upper part of the catchment.

PN was highly variable between sites and between surveys. The greatest variation occurred in the upper Kuparuk catchment. Annual average phosphate, TDP, DOP, and PP concentrations were consistently near and sometimes below the limits of detection (Table I). 


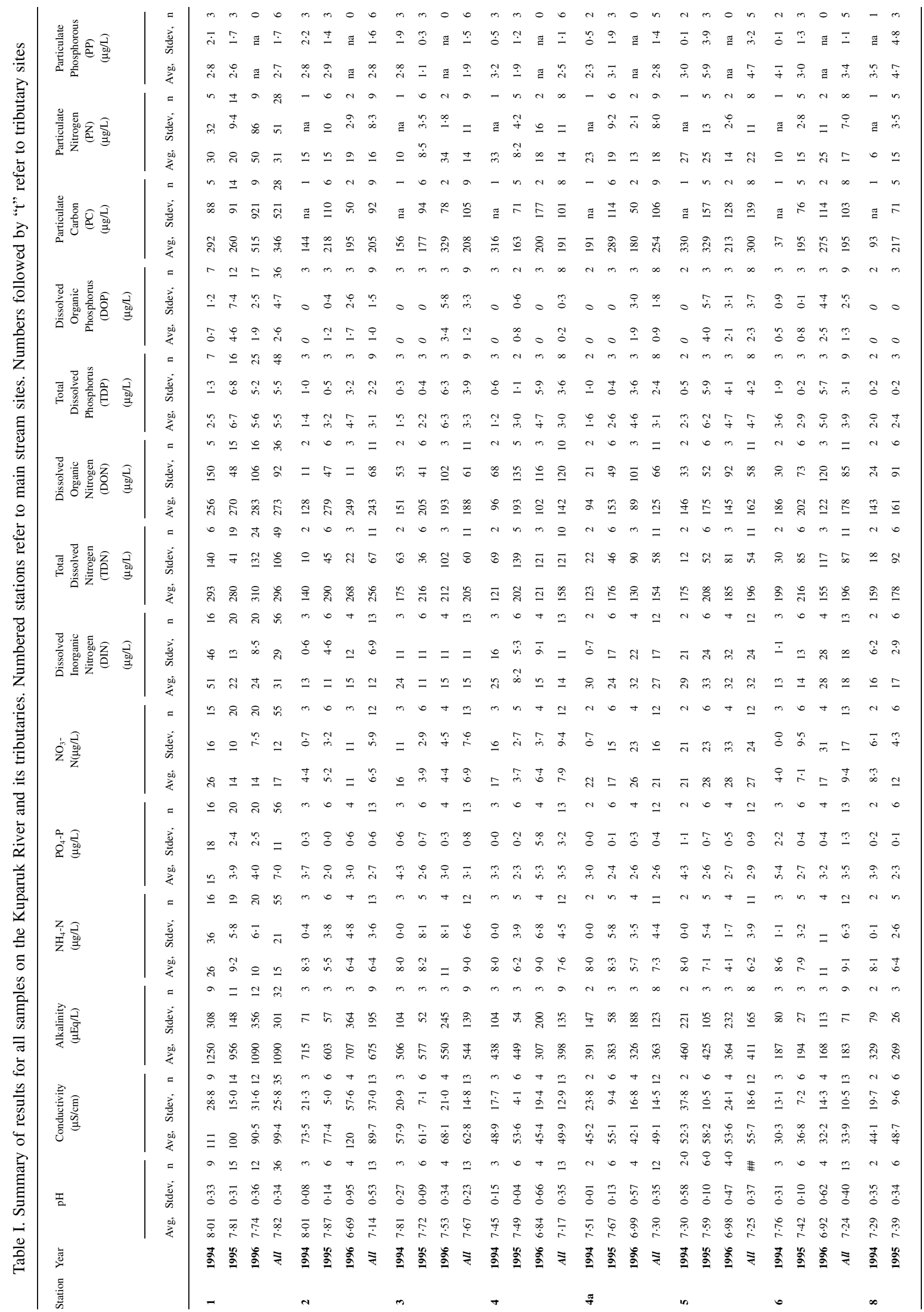




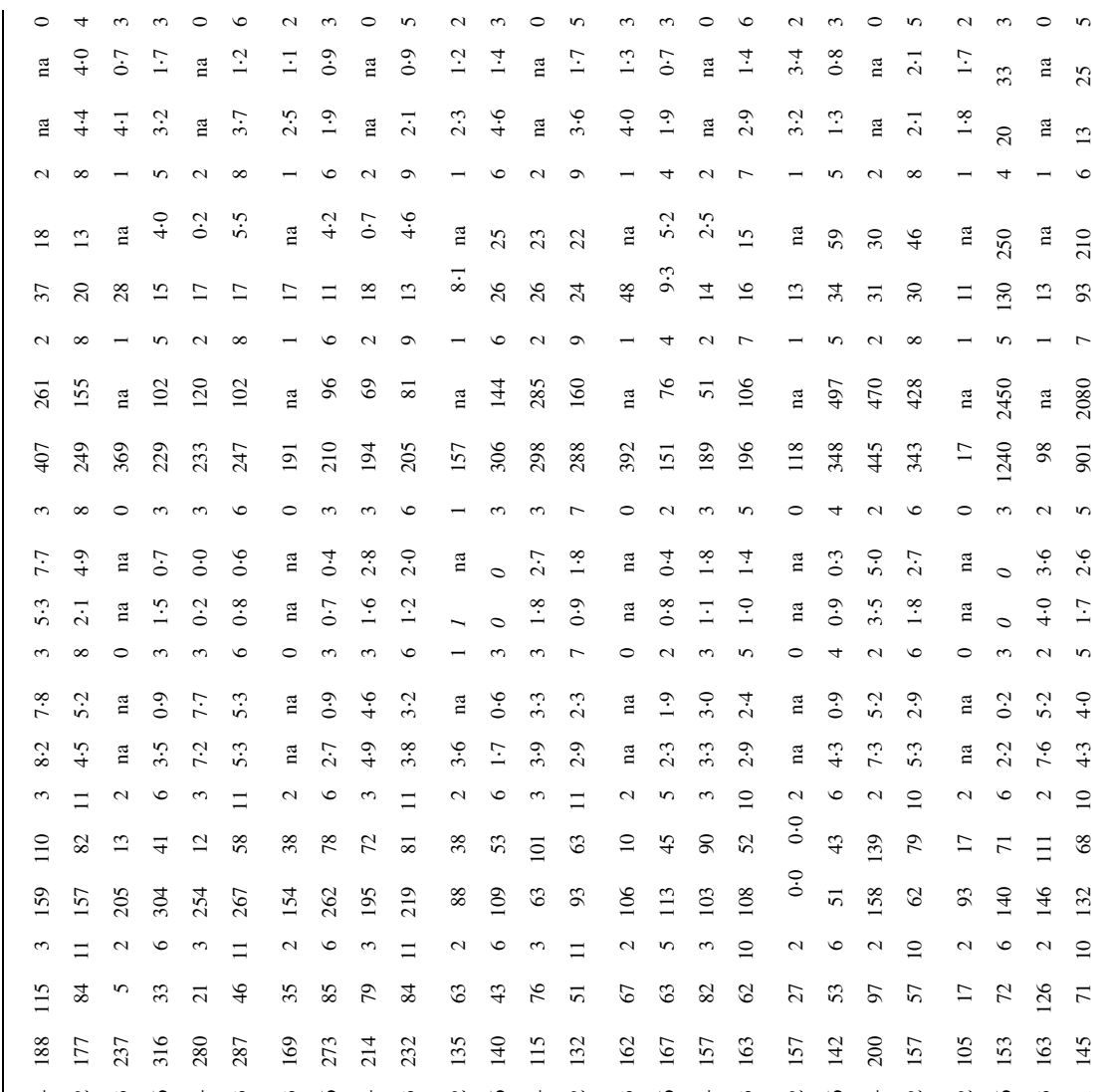

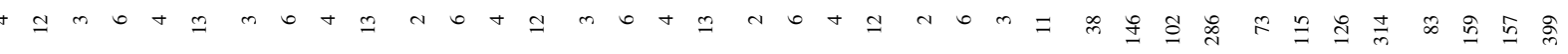

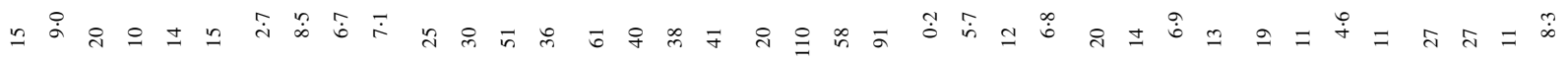

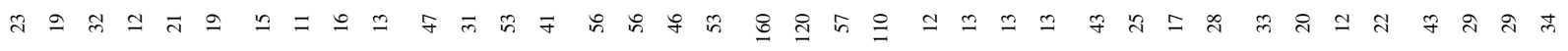

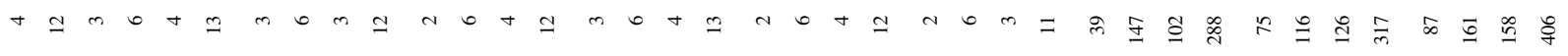

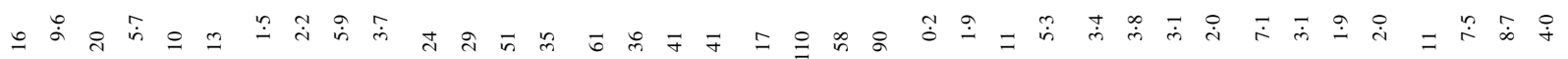

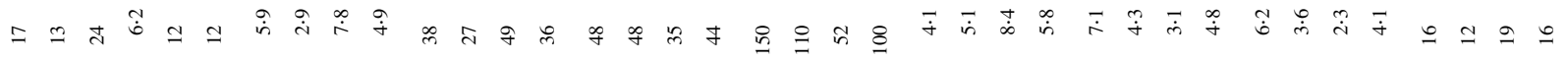

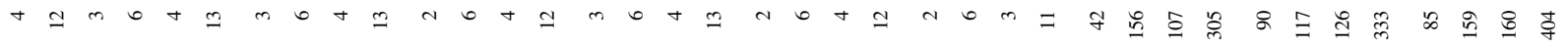

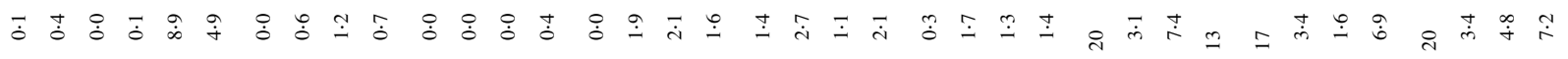

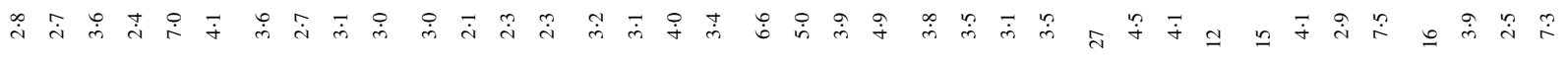

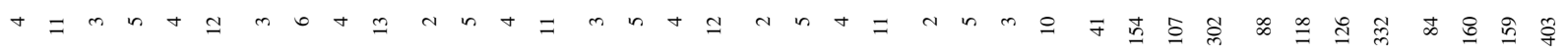

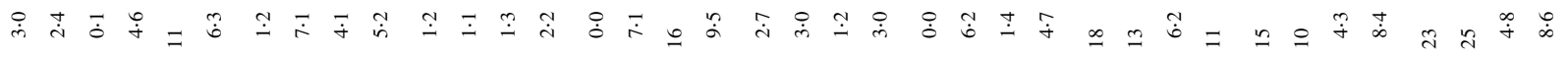

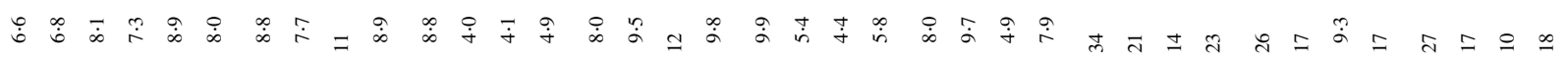

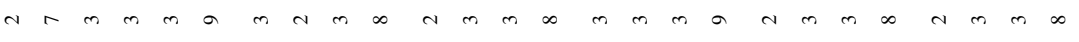

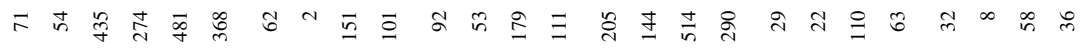

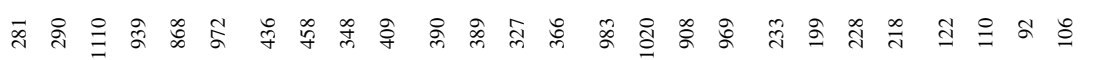

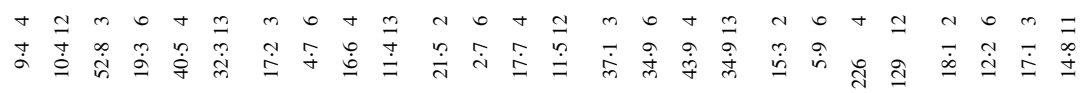

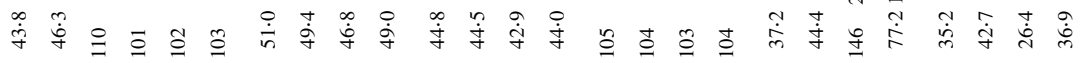

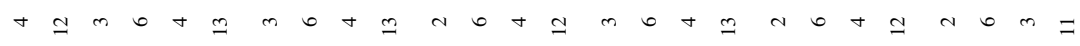

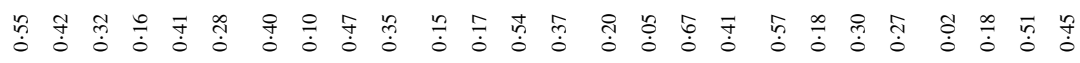

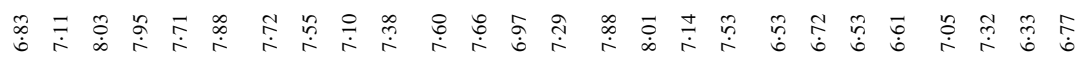

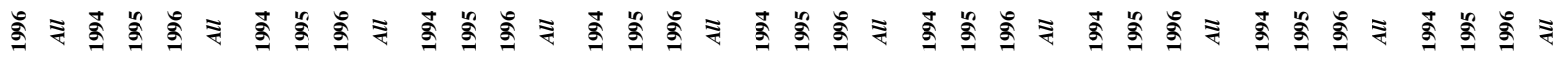
$\prod_{\infty} \quad$ वे 


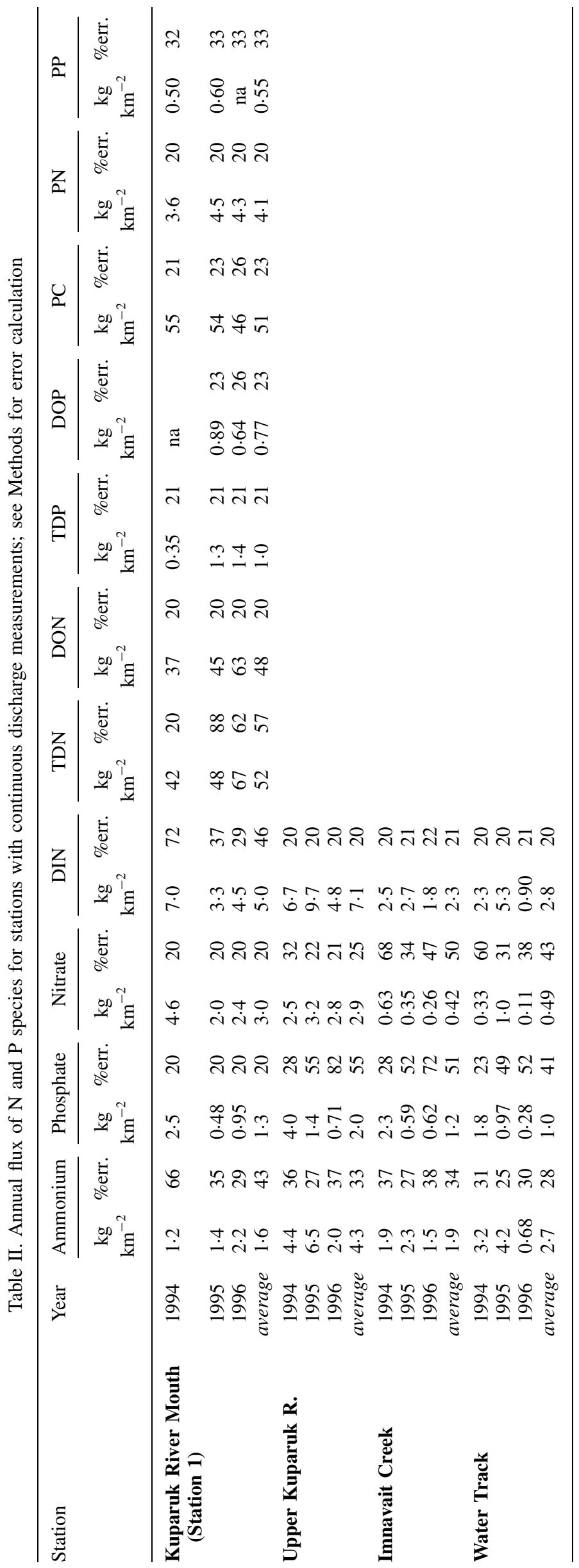


Table III. Proportion of annual nutrient and water flux during snowmelt and the largest summer storm for each catchment monitored

\begin{tabular}{|c|c|c|c|c|c|c|c|c|c|c|}
\hline & \multicolumn{5}{|c|}{ Snowmelt } & \multicolumn{5}{|c|}{ Largest summer storm } \\
\hline & $\mathrm{NH}_{4}-\mathrm{N}$ & $\mathrm{PO}_{4}-\mathrm{P}$ & {$\left[\mathrm{NO}_{3}^{-}-\mathrm{N}\right]$} & DIN & Water & $\mathrm{NH}_{4}-\mathrm{N}$ & $\mathrm{PO}_{4}-\mathrm{P}$ & {$\left[\mathrm{NO}_{3}^{-}-\mathrm{N}\right]$} & DIN & Water \\
\hline \multicolumn{11}{|c|}{ Lower Kuparuk River } \\
\hline 1994 & 0.68 & 0.94 & $0 \cdot 36$ & 0.53 & $0 \cdot 80$ & $0 \cdot 16$ & 0.03 & $0 \cdot 60$ & 0.42 & $0 \cdot 39$ \\
\hline 1995 & $0 \cdot 71$ & 0.73 & $0 \cdot 69$ & $0 \cdot 70$ & 0.52 & 0.05 & 0.09 & $0 \cdot 11$ & 0.09 & 0.07 \\
\hline 1996 & $0 \cdot 86$ & 0.91 & $0 \cdot 69$ & 0.78 & 0.69 & 0.03 & 0.05 & $0 \cdot 15$ & $0 \cdot 10$ & 0.08 \\
\hline Average & 0.75 & $0 \cdot 86$ & 0.58 & 0.67 & 0.67 & 0.08 & 0.06 & $0 \cdot 29$ & $0 \cdot 20$ & $0 \cdot 18$ \\
\hline \multicolumn{11}{|c|}{ Upper Kuparuk River } \\
\hline 1994 & $0 \cdot 26$ & 0.71 & $0 \cdot 36$ & $0 \cdot 31$ & 0.42 & $0 \cdot 12$ & 0.07 & 0.07 & $0 \cdot 10$ & $0 \cdot 10$ \\
\hline 1995 & $0 \cdot 25$ & $0 \cdot 25$ & $0 \cdot 11$ & $0 \cdot 20$ & 0.59 & $0 \cdot 31$ & $0 \cdot 22$ & $0 \cdot 25$ & $0 \cdot 29$ & $0 \cdot 19$ \\
\hline 1996 & 0.53 & 0.66 & $0 \cdot 37$ & 0.43 & 0.59 & $0 \cdot 01$ & 0.03 & 0.05 & 0.09 & 0.06 \\
\hline Average & $0 \cdot 34$ & $0 \cdot 54$ & $0 \cdot 28$ & $0 \cdot 31$ & $0 \cdot 39$ & $0 \cdot 14$ & $0 \cdot 11$ & $0 \cdot 12$ & $0 \cdot 16$ & $0 \cdot 11$ \\
\hline \multicolumn{11}{|c|}{ Imnavait Creek } \\
\hline 1994 & $0 \cdot 22$ & 0.58 & $0 \cdot 37$ & $0 \cdot 21$ & $0 \cdot 32$ & $0 \cdot 21$ & 0.08 & $0 \cdot 18$ & $0 \cdot 21$ & $0 \cdot 06$ \\
\hline 1995 & $0 \cdot 19$ & $0 \cdot 36$ & $0 \cdot 23$ & $0 \cdot 20$ & $0 \cdot 26$ & $0 \cdot 12$ & 0.07 & $0 \cdot 13$ & $0 \cdot 12$ & 0.06 \\
\hline 1996 & $0 \cdot 77$ & $0 \cdot 85$ & $0 \cdot 70$ & $0 \cdot 76$ & 0.75 & $0 \cdot 11$ & 0.07 & $0 \cdot 16$ & $0 \cdot 11$ & 0.09 \\
\hline Average & $0 \cdot 39$ & $0 \cdot 60$ & 0.44 & $0 \cdot 39$ & $0 \cdot 44$ & $0 \cdot 15$ & $0 \cdot 07$ & $0 \cdot 16$ & $0 \cdot 15$ & $0 \cdot 07$ \\
\hline \multicolumn{11}{|c|}{ Water track } \\
\hline 1994 & 0.03 & $0 \cdot 16$ & 0.09 & 0.06 & 0.04 & 0.08 & 0.06 & $0 \cdot 17$ & $0 \cdot 14$ & 0.03 \\
\hline 1995 & $0 \cdot 18$ & $0 \cdot 31$ & $0 \cdot 11$ & $0 \cdot 17$ & $0 \cdot 16$ & $0 \cdot 20$ & $0 \cdot 12$ & $0 \cdot 12$ & $0 \cdot 18$ & $0 \cdot 17$ \\
\hline 1996 & 0.78 & $0 \cdot 87$ & 0.75 & $0 \cdot 81$ & 0.75 & 0.07 & 0.03 & 0.08 & 0.06 & 0.06 \\
\hline Average & $0 \cdot 33$ & 0.44 & $0 \cdot 32$ & $0 \cdot 34$ & $0 \cdot 31$ & $0 \cdot 12$ & 0.07 & $0 \cdot 12$ & $0 \cdot 12$ & 0.09 \\
\hline
\end{tabular}
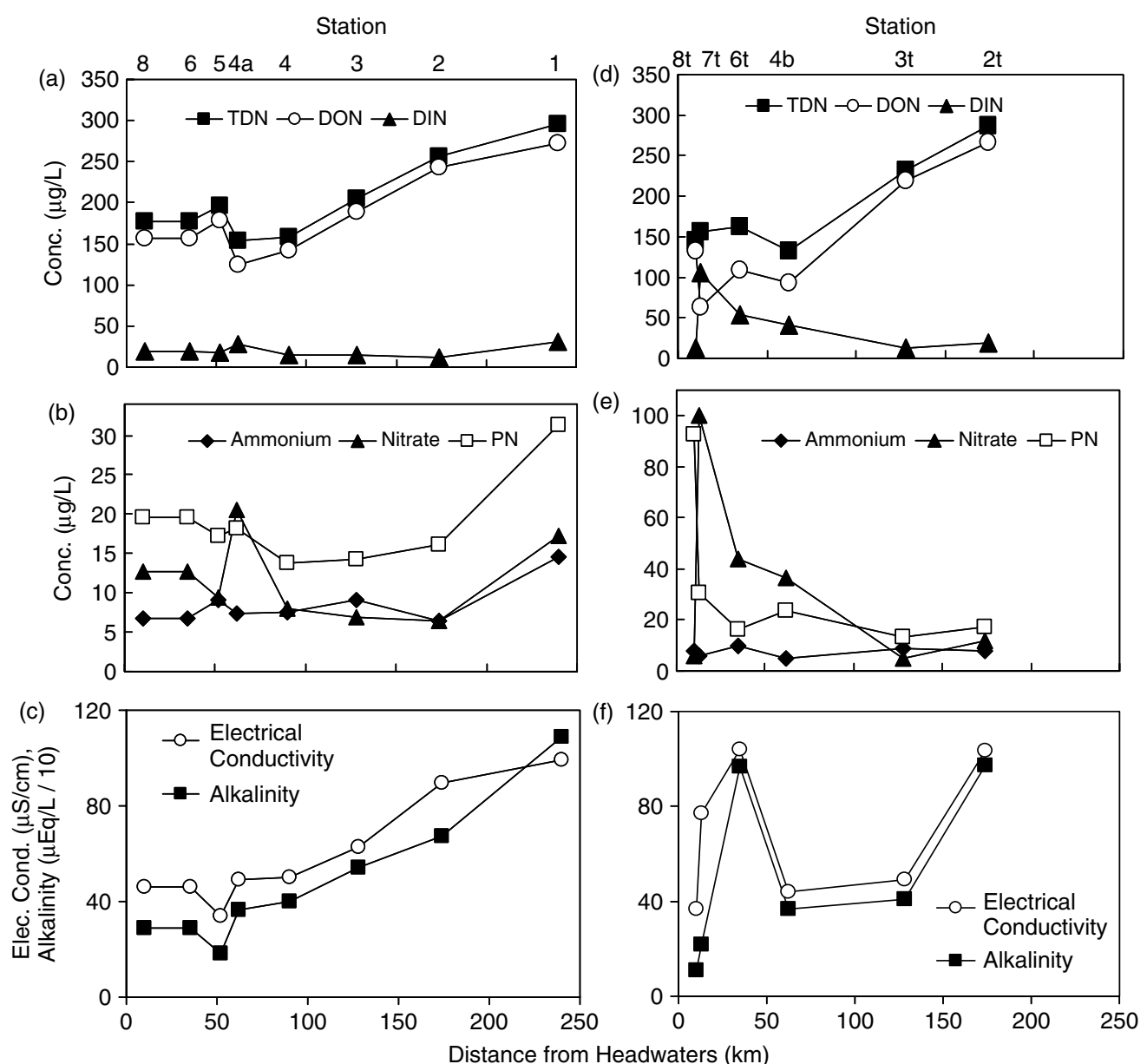

Figure 3. Downstream trends in average annual concentrations in the main stream of the Kuparuk of (a) TDN, DON, and DIN, (b) ammonium, nitrate, and PN, and (c) EC and alkalinity, and in tributaries of (d) TDN, DON, and DIN, (e) ammonium, nitrate, and PN, and (f) EC and alkalinity. All forms of $\mathrm{N}$ and $\mathrm{P}$ are given as the elemental weight. Standard deviations are given in Table I. Average annual P concentrations were consistently near the limits of detection and, therefore, are not included in this figure 


\section{Headwater catchments}

Average concentrations and fluxes. There are two key differences in average nutrient concentrations among headwater catchments. The hillslope water track had the highest average concentration of ammonium every year, and the Upper Kuparuk (as well as the Lower Kuparuk River) had much higher nitrate concentrations than Imnavait Creek and the hillslope water track (Table I). As a consequence, DIN tended to be dominated by nitrate in the Upper Kuparuk River, whereas DIN was strongly dominated by ammonium in the smaller Imnavait Creek and the water track. The annual average phosphate concentrations were similar among years and among rivers (Table I).

In these headwater catchments, snowmelt produced averages of $31-39 \%$ of annual water flux, although values ranged from $15 \%$ to $77 \%$ (Table III). As in the Lower Kuparuk River, nitrate and ammonium had ratios of snowmelt flux to annual flux that were similar to those for water. However, the same ratio for phosphate was typically higher, on average from $44 \%$ to $60 \%$. During summer storms these patterns tended to be reversed. The largest summer storms produced $\sim 3-19 \%$ of the annual water flux. The phosphate and water storm: annual ratios tended to be similar to one another, and the percentages of annual flux for nitrate and ammonium were slightly higher (Table III).

Concentration-time relations during snowmelt. Nitrate, ammonium, and phosphate concentrations in early streamflow in Imnavait Creek (Figure 4a) behaved similarly to concentrations in meltwater leaving the base of the snowpack. For example, at the base of the snowpack in 1994, meltwater concentrations of ammonium, nitrate, and phosphate decreased from $30 \mu \mathrm{g} \mathrm{l}^{-1}, 30 \mu \mathrm{g} \mathrm{l^{-1 }}$, and $58 \mu \mathrm{g} \mathrm{l}^{-1}$ respectively to their detection limits during the first 5 days of snowmelt. Similar patterns occurred in Imnavait Creek streamflow (Figure 4a). Following snowmelt, nitrate tended to remain low in Imnavait Creek but increased steadily in the Upper Kuparuk River (Figure 4b), just as it did in the Lower Kuparuk River. Ammonium concentrations typically increased just prior to or at peak flow, often to concentrations far above those of meltwater at the snowpack base. After the peak snowmelt flow, stream water ammonium concentrations tended to decrease through the recession (Figure $4 \mathrm{a}$ and $b$ ). Phosphate tended to increase and decrease with streamflow in the Upper Kuparuk River, but it was difficult to detect patterns for phosphate in Imnavait Creek.

During snowmelt, the nitrate:DIN ratio typically began high, dropped to a low point near the time of peak flow, and then increased through the recession (Figure 5). The decreasing nitrate: DIN ratio on the rising snowmelt hydrograph limbs in both streams was caused by increasing ammonium rather than decreasing nitrate, whereas the subsequent rise was controlled by increasing nitrate. The nitrate : DIN ratio remained high following snowmelt
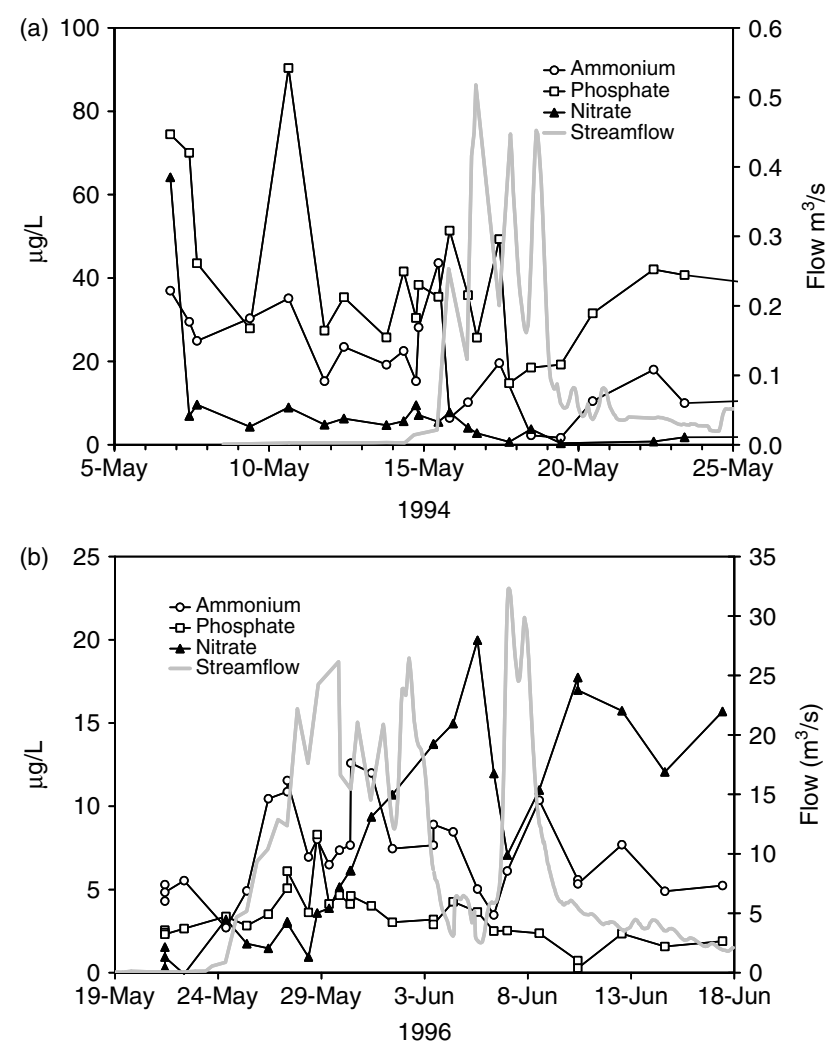

Figure 4. Time-series during snowmelt of dissolved inorganic nutrient concentrations (as weight of N or P) in Imnavait Creek in (a) 1994 and in the Upper Kuparuk River in (b) 1996. Other years had similar patterns, but are omitted for clarity

in the Upper Kuparuk River, whereas it decreased after early June in Imnavait Creek.

Concentration-time relations during rainstorms. The $\sim 30$ storms analysed during the study showed a wide range of responses among streams, storms, and solutes. Some common patterns were found, however, based on visual inspection of the time-series. Nitrate was consistently low in Imnavait Creek (Figure 6a), whereas nitrate in the Upper Kuparuk River (Figure 6b, EC not shown) tended to behave similarly to EC. Both variables tended to rise during interstorm periods, decrease with rising streamflow, and then increase as streamflow receded. However, nitrate commonly displayed a brief increase in concentration prior to the flow peak, whereas EC typically decreased immediately with the rising hydrograph. Conversely, phosphate tended to increase with rising streamflow (Figure 6). Following peak flow, phosphate tended to drop rapidly to pre-storm concentrations, then increase slightly during interstorm periods. Ammonium concentrations during storms were inconsistent and tended to behave differently among storms within a site, although there was a slight tendency for ammonium to increase as streamflow increased.

The nitrate: DIN ratios in Imnavait Creek were low $(<0.2$; Figure $7 \mathrm{a})$ and variations were controlled by changing ammonium concentrations. In the Upper Kuparuk River, however, the nitrate: DIN ratios were 

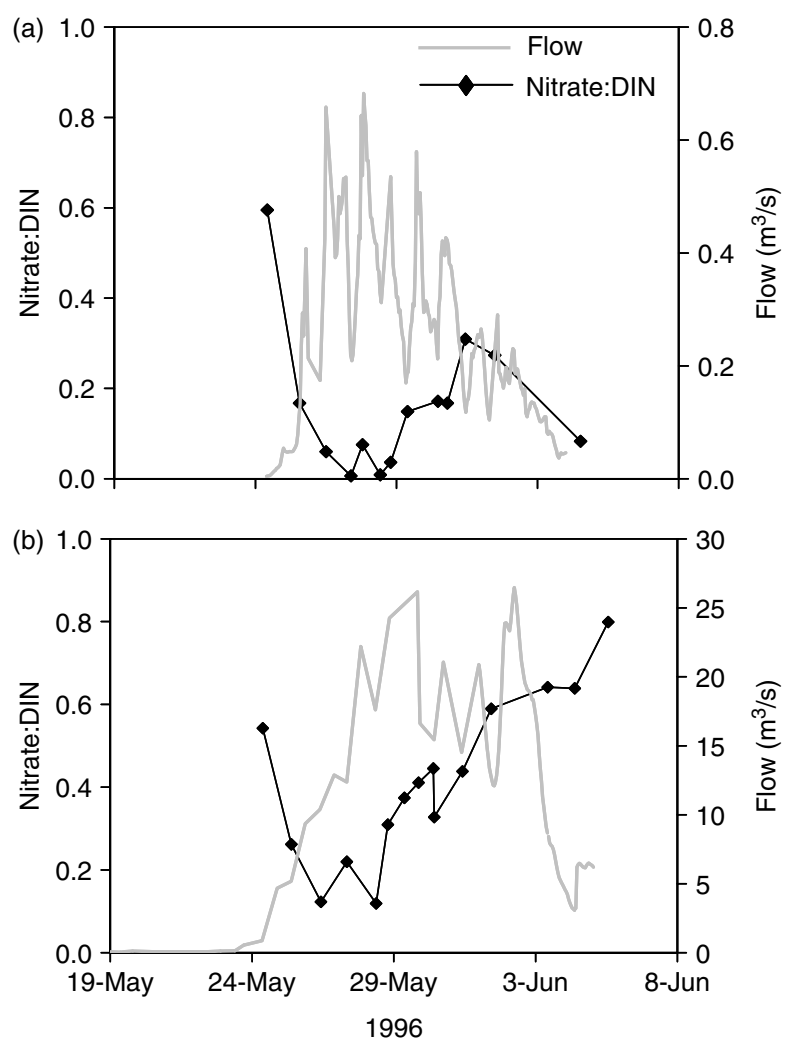

Figure 5. Time-series of the nitrate: DIN ratio in 1996 in (a) Imnavait Creek and (b) the Upper Kuparuk River
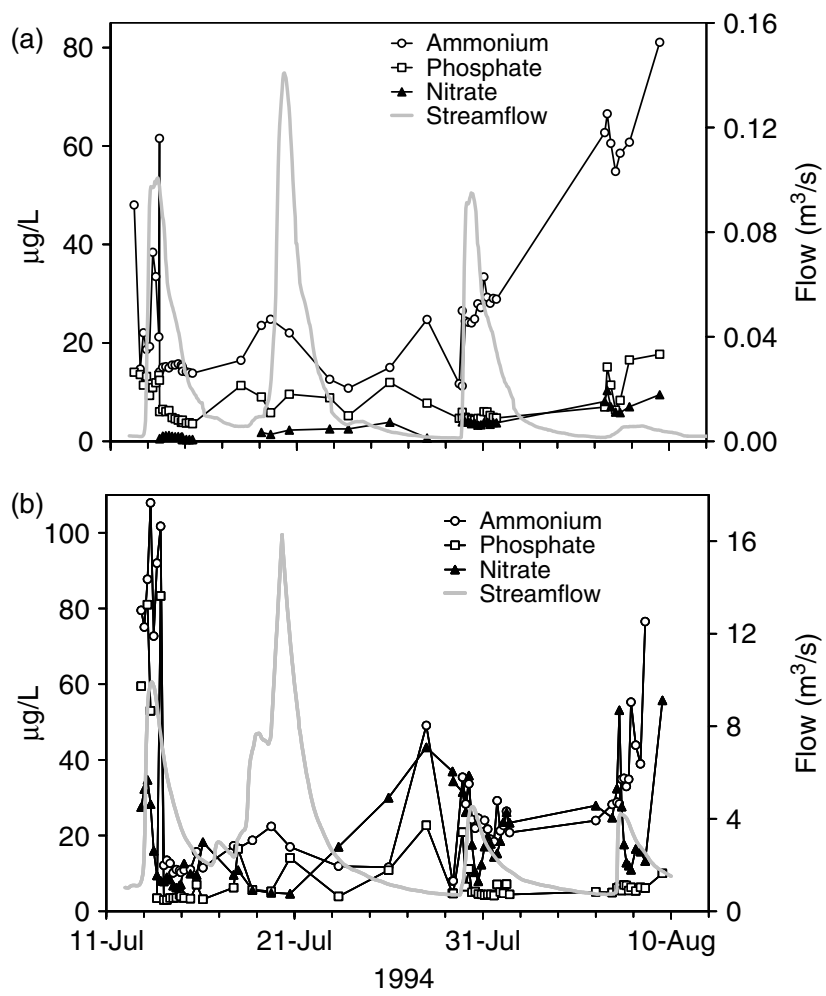

Figure 6. Time series of nutrient concentrations (as weight of $\mathrm{N}$ and $\mathrm{P}$ ) during a series of rainstorms in 1994 in (a) Imnavait Creek and (b) Upper Kuparuk River

higher and controlled by nitrate; this ratio tended to decrease as streamflow increased, reach a low coincident with the hydrograph peak, then increase as streamflow receded (Figure $7 b$ ). During rainstorms, the decreases in the nitrate:DIN ratios occurred because of decreases in nitrate, whereas during snowmelt it occurred because of increases in ammonium.

Concentration-discharge relationships. Nitrate was negatively correlated with discharge in the Upper Kuparuk River during snowmelt and summer periods (Table IV). Nitrate in Imnavait Creek, however, had a weak negative correlation with discharge only in 1995. Phosphate was positively correlated with discharge in all years in the Upper Kuparuk River, and in 1995 and 1996 in Imnavait Creek. Ammonium showed no consistent patterns of correlation with discharge in either stream for the entire year, although during summers in the Upper Kuparuk River ammonium and discharge tended to be positively correlated (Table IV).

In the Upper Kuparuk River during snowmelt, ammonium displayed clockwise hysteresis with higher concentrations during rising flows, whereas nitrate and EC both had very high values during early low flows and were followed by essentially non-hysteretic concentrationdischarge relationships (Figure $8 \mathrm{a}-\mathrm{c}$ ). During rainstorms, ammonium, nitrate, and EC tended to behave similarly. When hysteresis existed it was clockwise for all three variables (Figure $8 \mathrm{~d}-\mathrm{f}$ ), tending to be pronounced following extended dry periods and low or non-existent following wetter periods (Figure $8 \mathrm{~g}-\mathrm{i}$ ). Phosphate showed no clear examples of hysteresis.
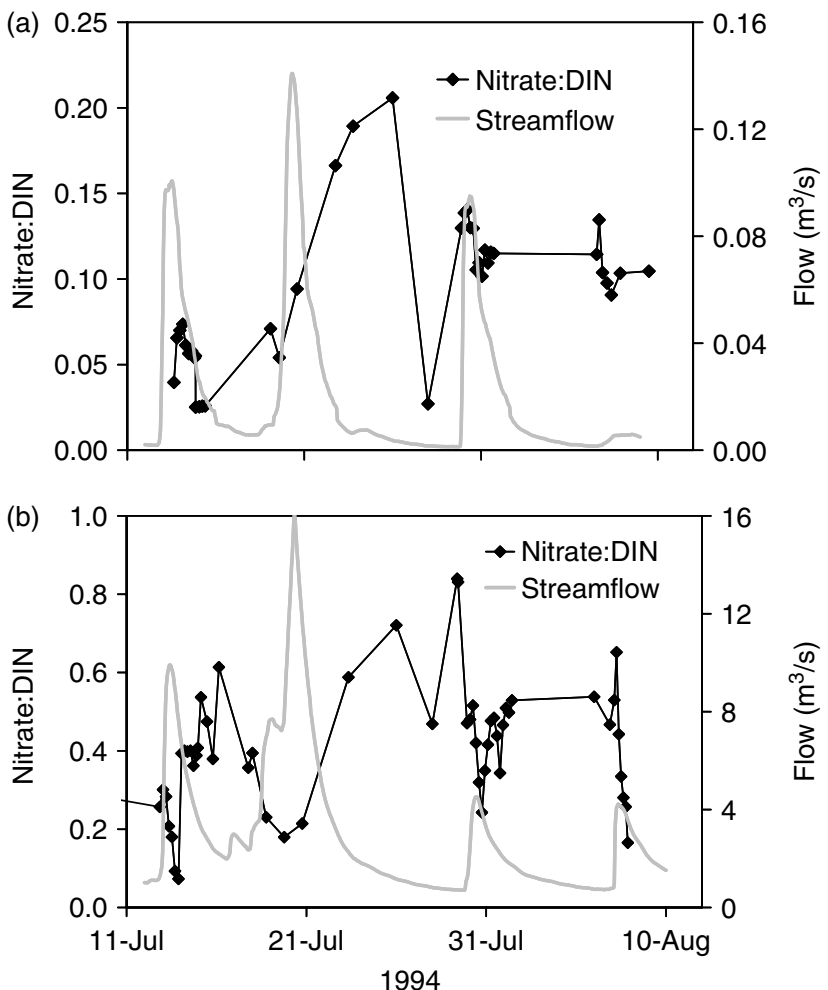

Figure 7. Time-series of the nitrate: DIN ratio during a series of rainstorms in 1994 in (a) Imnavait Creek and (b) Upper Kuparuk River 
Table IV. Pearson correlation coefficients between discharge and nutrient concentrations that are significant at $\alpha=0.05$

\begin{tabular}{|c|c|c|c|c|c|c|}
\hline \multirow[t]{2}{*}{ Sample } & \multicolumn{3}{|c|}{ Imnavait Creek } & \multicolumn{3}{|c|}{ Upper Kuparuk River } \\
\hline & $\mathrm{NH}_{4}-\mathrm{N}$ & $\mathrm{PO}_{4}-\mathrm{P}$ & {$\left[\mathrm{NO}_{3}^{-}-\mathrm{N}\right]$} & $\mathrm{NH}_{4}-\mathrm{N}$ & $\mathrm{PO}_{4}-\mathrm{P}$ & {$\left[\mathrm{NO}_{3}^{-}-\mathrm{N}\right]$} \\
\hline 94 all & -0.25 & & & & $0 \cdot 22$ & $-0 \cdot 37$ \\
\hline 95 all & & $0 \cdot 28$ & $-0 \cdot 20$ & $0 \cdot 21$ & $0 \cdot 21$ & $-0 \cdot 22$ \\
\hline 96 all & & $0 \cdot 21$ & & & $0 \cdot 36$ & $-0 \cdot 56$ \\
\hline 94 snowmelt & & & & & & -0.52 \\
\hline 95 snowmelt & & & & & & -0.70 \\
\hline 96 snowmelt & & & & & 0.50 & \\
\hline 94 summer & & & & 0.42 & $0 \cdot 36$ & -0.35 \\
\hline 95 summer & & & $-0 \cdot 28$ & $0 \cdot 20$ & $0 \cdot 18$ & $-0 \cdot 15$ \\
\hline 96 summer & & & & & & -0.43 \\
\hline
\end{tabular}

(a)

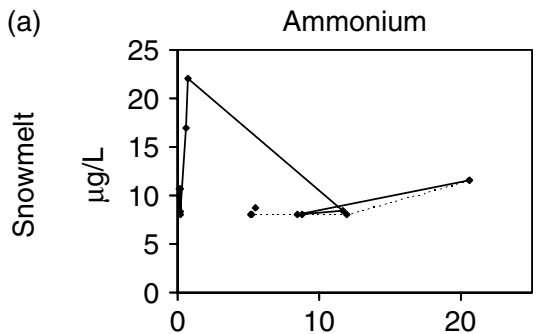

(d)

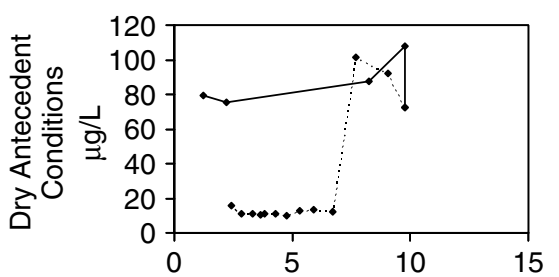

(g)

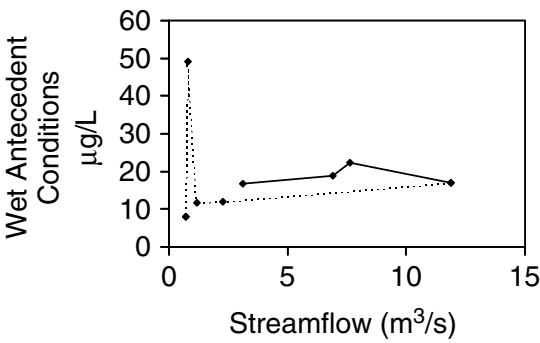

(b)

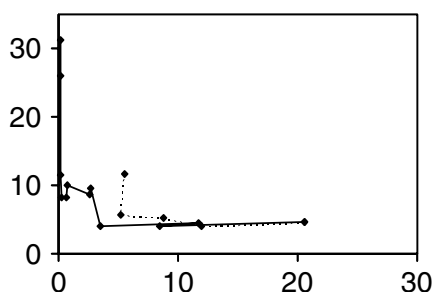

(e)

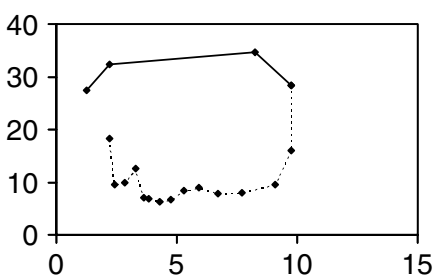

(h)

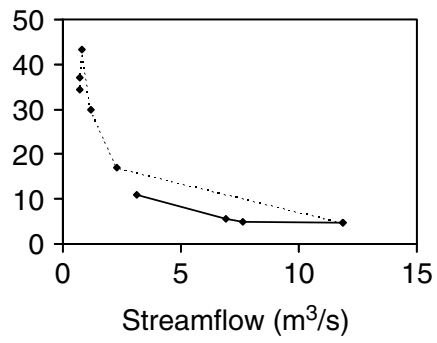

(c) Electrical Cond.

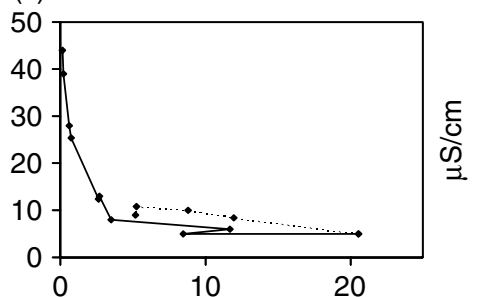

(f)
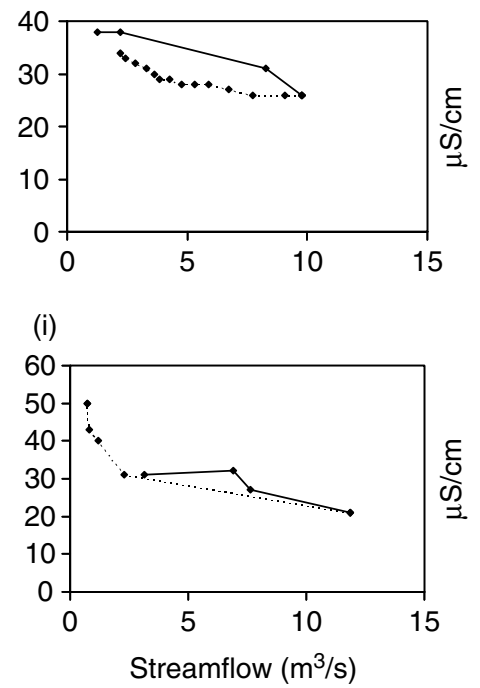

Figure 8. Concentration-discharge plots during one snowmelt event (10 May) and two rainstorms in 1995 in the Upper Kuparuk River (12 July, dry antecedent conditions; 17 July, wet antecedent conditions). Solid lines represent ascending hydrographs and dotted lines are descending hydrographs

\section{DISCUSSION}

Comparison with world average concentrations and fluxes

The average nitrate concentration represents the largest difference between nutrients in the Kuparuk River and in rivers of the world. Our basis of comparison is Meybeck (1982), who reported average nutrient concentrations for rivers worldwide, as well as for important representative biomes, including tundra regions. Nitrate concentrations and loads in the Kuparuk River were considerably lower than world averages, whereas ammonium and DON concentrations were relatively similar to world averages. Phosphate concentrations were approximately half of the world average. Whereas ammonium was approximately half of DIN in the Kuparuk River, the same concentration was only $15 \%$ of the world average DIN. The average TDN in the Kuparuk River $\left(296 \mu \mathrm{g}^{-1}\right)$ was moderately lower than the world average $\left(375 \mu \mathrm{g}^{-1}\right)$. DON was only moderately higher in the Kuparuk River $\left(273 \mu \mathrm{g}^{-1}\right.$ versus $260 \mu \mathrm{g} \mathrm{l}^{-1}$ world average), but the DON:TDN ratio was considerably higher in the Kuparuk River than in the world average (92\% versus 69\%). Other studies have reported that DON typically constitutes 10 to $70 \%$ of DIN in freshwaters (Willett et al., 2004).

High DON:TDN ratios, like those found in the Kuparuk River, are typical of natural conditions in unpolluted regions, whereas higher DIN inputs from 
atmospheric deposition in polluted areas cause lower ratios of DON : TDN in streamflow (Perakis and Hedin, 2002). It is notable, however, that high DON : TDN ratios can be found even when DIN deposition (Pellerin et al., 2004; Balestrini et al., 2006) or additions (Campbell et al., 2000) are high, just as low DON : TDN ratios can occur when DIN deposition is low (Bernal et al., 2005), suggesting that deposition of DIN from pollution is not necessarily the primary control on DON : TDN ratios.

The annual fluxes of all forms of dissolved $\mathrm{N}$ in the Kuparuk River were considerably lower than world averages, even when concentrations were similar, due to low annual discharge (Table II). Snowmelt and rainstorms had a strong impact on $\mathrm{N}$ and $\mathrm{P}$ export on daily time-scales in the headwater catchments (Table III). While snowmelt was consistently a time of high flux, the daily flux (kilograms per day) of $\mathrm{N}$ and $\mathrm{P}$ during summer storms occasionally exceeded that during snowmelt in headwater catchments. This agrees with Kane et al. (2003), who suggested that although, snowmelt floods are consistently high, the largest floods on record will likely be generated by rain.

\section{Spatial variability: the impact of tundra vegetation and soils}

Arctic environments have two conditions that favour high DON : TDN ratios and low nitrate concentrations. First, tundra vegetation is extremely nutrient limited and strongly retains inorganic N (Chapin et al., 1980; Dowding et al., 1981; Kling, 1995; Brooks and Williams, 1999; Satoru et al., 2006); these studies show that $\mathrm{N}$ that is added to tundra by fixation, deposition, or mineralization is quickly taken up by plants, so that nitrate mobility is limited. Second, tundra soils tend to be easily waterlogged and routinely anoxic due to shallow active layers underlain by permafrost and to low hydrologic gradients (Gebauer et al., 1995). Such conditions limit the oxidation of ammonium to nitrate (nitrification). However, when soil waters reach stream banks, there is greater potential for exposure to oxygen and the ratio of ammonium to nitrate decreases, as shown previously for the Lower Kuparuk River (Kling, 1995). For example, the ammonium : nitrate ratios were highest in the water track and Imnavait Creek (4.8 and 4.1 respectively by weight, derived from Table I), and decreased in the larger, more open and oxygenated environments of the Upper Kuparuk River and Lower Kuparuk River (1.1 and 0.88 respectively, derived from Table I). In terms of overall controls on $\mathrm{N}$ species in streams, it is possible that soil water status is a second cause of low nitrate concentrations and high DON : TDN ratios. This interpretation is consistent with the data in Perakis and Hedin (2002) (but does not rely on their explanation of low anthropogenic DIN inputs), because most of their study catchments had high precipitation rates. Likewise, high DON : TDN ratios were found in a study of an alpine tundra environment with high precipitation (Balestrini et al., 2006), and Pellerin et al. (2004) showed that increasing wetland area in a catchment increased the DON:TDN of stream water.
The potential impact of wetland soils, which become more prevalent towards the coast, is illustrated by the differences between downstream trends in the mainstream and northward trends in tributary mouths in DON, alkalinity, and EC (Figure 3). In the mainstream, DON, alkalinity, and EC increase downstream (northward), likely due to increased streambed weathering associated with longer residence times in the river. However, in the tributary mouths, DON increases northward and alkalinity and EC do not, suggesting an alternative explanation for the northward DON increase. Because the tributaries drain independent catchments, we suggest that spatial trends are related to regional features, such as land cover transitions or biotic processes. We also suggest that the northward DON increase may result in part from an increase in the area of land covered by peat; other possibilities include lower hydrologic gradients, which promote anoxic soils, and colder temperatures, which slow rates of decomposition.

\section{Temporal variability: the role of flow, water source, and chemical reactions}

Nutrient concentrations in streams vary through time in response to numerous factors, including discharge, temperature, evaporation, and biogeochemical transformations, among others. The interaction of these factors results in poor correlations of water chemistry with any single variable. Further, each solute responds to environmental drivers in different ways. For example, phosphate and discharge tend to be positively correlated, whereas nitrate and discharge tend to be negatively correlated (Table IV); and snowmelt is the major flux event for phosphate, whereas summer rainstorms can be as important as snowmelt for nitrate (Table III). An approach to help separate the hydrologic and biogeochemical controls is to consider the relationships between nutrients and EC. EC can be considered an analogue for total dissolved solids (dominated by base cations), which respond to hydrologic drivers such as storms on short time-scales and geochemical drivers, such as weathering, on longer time-scales.

Phosphate is not correlated with EC in space or time at any of our sampling sites. Nitrate and EC are also not spatially correlated (EC increases downstream in the Kuparuk River whereas nitrate does not); however, they do tend to behave similarly in time at any particular site. Both tend to be inversely correlated with discharge (Table IV), co-vary through the summer in the Lower Kuparuk River (Figure 2), exhibit similar hysteresis patterns during storms in the Upper Kuparuk River (Figure 8), and have very low concentrations in the small, peaty catchments (Table I). As discussed in the previous section, the primary source of in-stream nitrate is likely nitrification in the near-stream oxygenated soils or possibly the hyporheic zone. Base cations are likely derived from weathering of the mineral substrate. The lack of spatial correlation between EC and nitrate attests to different fates of inorganic solutes and biologically active nutrients. The downstream EC increase likely results from 
in-stream weathering processes, whereas nitrate is likely consumed by aquatic organisms.

The different correlations with discharge for each nutrient (Table IV) can possibly be explained by the behaviour of nutrients during storms. Storms add new, relatively dilute water to catchments, initiate previously dormant hydrologic pathways, and mobilize labile solutes so that nutrient concentrations in streams are impacted by a complicated mix of flushing, end-member mixing, and biogeochemical transformations. It is worth considering snowmelt and rain-generated storms separately given the following differences: snowmelt follows an extended period of hydrologic inactivity of up to 9 months, whereas rainstorms are typically separated by only days or weeks (McNamara et al., 1998); biogeochemical activity is reduced in the winter relative to summer interstorm periods; snowmelt runoff has minimal interaction with the subsurface, whereas subsurface flow during rainstorms may occur in the thawed active layer (McNamara et al., 1997); and melting snow releases solute pulses prior to the main meltwater pulse (Williams et al., 1995; Quinton and Pomeroy, 2006).

Because streamflow is predominantly composed of new meltwater during snowmelt (McNamara et al., 1997), mixing of source waters (i.e. event and preevent water) is not a likely cause of nutrient concentration variability in snowmelt-generated streamflow. We suggest that nitrate is primarily controlled by initial concentrations in the snowpack, whereas ammonium is flushed from a thin layer of soil and vegetation at the base of the snowpack. This layer is water saturated and probably anoxic, so that microbial degradation of organic matter leads to higher ammonium than nitrate concentrations. The primary evidence is that, following initial high concentrations due to solute exclusion (e.g., Williams et al., 1995), nitrate tends to remain low through increasing snowmelt streamflow, which contributes to the negative correlation between nitrate and streamflow (Table IV). In contrast, ammonium tends to increase and peak at levels that exceed concentrations in melting snow (Figure 4a). Thus, as the flow season begins, melting snow and the uppermost soil and moss layers likely contribute ammonium-rich water to the streams. As the snowmelt flood progresses, nitrification in the stream (and perhaps at the soil-snow interface) converts ammonium to nitrate and contributes to the observed clockwise concentration-discharge hysteresis loop for ammonium (Figure 8a) and to the increase in nitrate on the descending hydrograph limb in the Upper Kuparuk River (Figure 4), which further contributes to the negative correlation between nitrate and streamflow. This interpretation is also consistent with how the nitrate: DIN ratio increases after peak snowmelt discharge (Figure 5). Similar to nitrate, high concentrations of phosphate in early snowmelt are likely due to solute exclusion or wind-blown loess stored in the snowpack (Figure 4a). However, unlike nitrate, phosphate tends to increase and decrease with streamflow during snowmelt, leading to the positive correlation between the two variables. This suggests that, similar to ammonium, flushing of a thin and thawed saturated soil zone may contribute phosphate to streams. It is possible that phosphate is also mobilized from the streambed.

Following snowmelt, soils begin to thaw and thus promote hydrologic interaction with the subsurface (McNamara et al., 1997). During extended dry periods between storms, ammonium and nitrate tend to accumulate in soil water due to various processes such as decomposition (e.g. Inamdar et al., 2006). The nutrients accumulated during interstorm periods are flushed during storms and, thus, cause the clockwise hysteresis in nitrate and ammonium concentration-discharge relationships (Figure 8). The two storms with the most extreme hysteresis (12 July and 29 July in Figure 7) were preceded by the driest soil conditions (McNamara et al., 1998). These results illustrate that flushing frequency influences nitrate delivery to streams, which is similar to findings for temperate-zone catchments (Burns et al., 1998).

Although nitrate and ammonium tend to behave differently between rain- and snowmelt-generated flows, it is interesting that the patterns of change in nitrate: DIN appear similar at these different times of year. Changes in ammonium tend to control the nitrate: DIN ratio during snowmelt. At the beginning of most rainstorms, however, the soils are less saturated, more oxic, and, therefore, the ammonium concentrations are less important in altering the nitrate : DIN ratio over time, again highlighting the role of stored precipitation and saturated soils in catchment hydrogeochemistry. Further, in all cases where concentration-discharge hysteresis exists it has a clockwise direction, indicating a supply-limited system as opposed to a transport-limited system. This is consistent with the conclusion that nutrient concentrations in this arctic catchment are generally lower than in many other regions.

\section{CONCLUSIONS}

Concentrations and fluxes of $\mathrm{N}$ and $\mathrm{P}$ in the Kuparuk River and its tributaries are strongly controlled by arctic conditions, including the presence of permafrost, the high occurrence of waterlogged anoxic soils, $\mathrm{N}$ retention in tundra environments, low annual discharge, and the importance of snowmelt as a hydrologic driver. These conditions distinguish the Kuparuk River, and presumably other arctic rivers, from rivers in more temperate environments, with the key distinction being very low nitrate concentrations and high DON : TDN ratios. Nitrate concentrations and nitrate:DIN ratios increase from the peat-dominated catchments of headwater streams to the more oxygenated, larger alluvial headwater streams. Consequently, the spatial patterns of nitrate and ammonium in stream water are controlled by the presence of anoxic soils in catchments. Temporal patterns of DIN concentrations tend to be dominated by the frequency of rainstorms. For example, storms that follow 
extended dry periods tend to produce extreme hysteresis in concentration-discharge relationships for nitrate, ammonium, and EC. Because spring snowmelt is the primary source of water flux (over 60\% of the annual total at the Lower Kuparuk River), nutrient flux during snowmelt is high and the proportion of annual nitrate flux during snowmelt is similar to the proportion of water flux. However, ammonium and phosphate flux during snowmelt tends to be higher than the proportional water flux. These differences in nutrient flux can be explained by the different responses of nitrate, ammonium, and phosphate to snowmelt. That is, ammonium and phosphate tend to be flushed from storage during the snowmelt, nitrate is generally controlled by the concentration of meltwater with little additional input from soils, and phosphate likely has both snow and soil sources. Given the dependence of nutrient concentrations and the timing of export on arctic conditions, future work should focus on potential changes in these conditions that may occur as the Arctic responds to climate warming.

\section{ACKNOWLEDGEMENTS}

This work was funded in part by the National Science Foundation grants OPP-9318535, OPP-9814984, and OPP-0335941 to the University of Alaska, Fairbanks, DEB-9810222, DEB-0423385, OPP-9911278, OPP9318529, and ATM-0439620 to the University of Michigan, and OPP-0327440 to Boise State University as a subcontract from the University of Vermont. We thank Chris Harvey, Richard Smith, Huan Luong, Larry Hinzman, Peder Yurista, Cecelia Sheridan, Megan Ridley, and Chris Wallace for field and laboratory work, and we appreciate the comments of three anonymous reviewers.

\section{REFERENCES}

Balestrini R, Martino N, VanMiegroet H. 2006. Nitrogen cycling and mass balance for a forested catchment in the Italian Alps. Assessment of nitrogen status. Biogeochemistry 78: 97-123.

Bernal S, Butturini A, Sabater F. 2005. Seasonal variations of dissolved nitrogen and DOC:DON ratios in an intermittent Mediterranean stream. Biogeochemistry 75: 351-372.

Best H. 2002. The influence of ice on channel morphology of the Kuparuk River, Alaska. Master's thesis, Boise State University.

Best H, McNamara JP, and Liberty L. 2005. Association of ice and river channel morphology determined using ground penetrating radar in the Kuparuk River, Alaska. Arctic, Antarctic, and Alpine Research 37(2): $157-162$.

Brooks PD, Williams MW. 1999. Snowpack controls on nitrogen cycling and export in seasonally snow-covered catchments. Hydrological Processes 13: 2177-2190.

Burns DA. 2005. What do hydrologists mean when they use the term flushing? Hydrological Processes 19: 1325-1327.

Burns DA, Hooper RP, McDonell JJ, Freer JE, Kendal C, Beven K. 1998. Base cation concentrations in subsurface flow from a forested hillslope: the role of flushing frequency Water Resource Research 34: 3535-3544

Campbell JL, Hornbeck JW, McDowell WH, Buso DC, Shanley JB, Likens GE. 2000. Dissolved organic nitrogen budgets for upland forested ecosystems in New England. Biogeochemistry 49: 123-142.

Chapin FSI, Miller PC, Billings WD, Coyne PI. 1980. Carbon and nutrient budgets and their control in coastal tundra. In An Arctic Ecosystem: the Coastal Tundra at Barrow, Brown J, Miller PC,
Tieszen LL, Bunnell FL (eds). Dowden, Hutchinson \& Ross: Stroudsburg; 458-482.

Creed IF, Band LE, Foster NW, Morrison IK, Nicolson JA, Semkin RS, Jeffries DS. 1996. Regulation of nitrate-N from temperate forests: a test of the $\mathrm{N}$ flushing hypothesis. Water Resources Research 32: 3337-3354.

Déry SJ, Stieglitz M, Rennermalm AK, Wood EF. 2005. The water budget of the Kuparuk River Basin, Alaska. Journal of Hydrometeorology 6: $633-655$

Dittmar T. 2004. Evidence for terrigenous dissolved organic nitrogen in the Arctic deep sea. Limnology and Oceanography 49: 148-156.

Dittmar T, Kattner G. 2003. The biogeochemistry of the river and shelf ecosystem of the Arctic Ocean: a review. Marine Chemistry 83: $103-120$.

Dowding P, Chapin FSI, Wielgolaski FE, Kilfeather P. 1981. Nutrients in tundra ecosystems. In Tundra Ecosystems, A Comparative Analysis, Bliss LC, Heal OW, Moore JJ (eds). Cambridge University Press: Cambridge; 647-683.

Gebauer LE, Tenhunen JD, Reynolds JF. 1995. Soil aeration in relation to soil physical properties, nitrogen availability, and root characteristics within and arctic watershed. Plant and Soil 178: 1573-5036.

Giblin AE, Nadelhoffer KJ, Shaver GR, Laundre JA. 1991. Biogeochemical diversity along a riverside toposequence in arctic Alaska. Ecological Monographs 61: 415-435.

Gilliom RJ, Helsel RD. 1986. Estimation of distributional parameters for censored trace level water quality data. 1. Estimation techniques. Water Resources Research 22: 135-146.

Hamilton TD. 1986. Late Cenezoic glaciation of the Central Brooks Range. In Glaciation in Alaska: the Geologic Record, Hamilton TD, Reed KM, Thorson RM (eds). Alaska Geological Society; 9-49.

Hinzman LD, Kane DL, Gieck RE, Everett KR. 1991. Hydrologic and thermal properties of the active layer in the Alaskan Arctic. Cold Regions Science and Technology 19: 95-110.

Hinzman LD, Bettez ND, Bolton WR, Chapin FSI, Dyurgerov MB, Fastie CL, Griffith B, Hollister RD, Hope A, Huntington HP, Jensen AM, Jia GJ, Jorgenson T, Kane DL, Klein DR, Kofinas G, Lynch AH, Lloyd AH, McGuire AD, Nelson FE, Oechel WC, Osterkamp TE, Racine CH, Romanovsky VE, Stone RS, Stow DA, Sturm M, Tweedie CE, Vourlitis GL, Walker MD, Walker DA, Webber PJ, Welker JM, Winker KS, Yoshikawa K. 2005. Evidence and implications of recent climate change in northern Alaska and other Arctic regions. Climate Change 72: 251-298.

Houghton JT, Ding Y, Griggs DJ, Noguer M, van der Linden PJ, Dai X, Maskell K, Johnson CA. 2001. Climate Change 2001: The Scientific Basis. Contribution of Working Group I to the Third Assessment Report of the Intergovernmental Panel on Climate Change. Cambridge University Press: Cambridge, UK.

Inamdar SP, O'Leary N, Mitchel MJ, Riley JT. 2006. The impact of storm events on solute exports from a glaciated forested watershed in western New York, USA. Hydrological Processes 20: 3423-3439.

Kane DL, McNamara JP, Yang D, Olson PQ, Gieck RE. 2003. An extreme rainfall event in Arctic Alaska. Journal of Hydrometeorlogy 4: $1220-1228$.

Kane DL, Gieck RE, Kitover DC, Hinzman LD, McNamara JP, Yang D. 2004. Hydrological cycle on the North Slope of Alaska. In Northern Research Basins Water Balance, Kane DL, Yang D (eds). IAHS Publication No. 290. IAHS Press: Wallingford; 224-236.

Kashulina G, Reimann C, Finne TE, de Caritat PN, Niskavaara H. 1998. Factors influencing $\mathrm{NO}_{3}$ concentrations in rain, stream water, ground water and podzol profiles of eight small catchments in the European Arctic. Environmental Pollution 102: 559-568.

Kling GW. 1995. Land-water linkages: the influence of terrestrial diversity on aquatic systems. In The Role of Biodiversity in Arctic and Alpine Tundra Ecosystems, Chapin FS, Korner C (eds). Springer: Berlin; 297-310.

Kling GW, O’Brien WJ, Miller MC, Hershey AE. 1992. The biogeochemistry and zoogeography of lakes and rivers in arctic Alaska. Hydrobiologia 240: 1-14.

Kling GW, Kipphut GW, Miller MC, O'Brien WJ. 2000. Integration of lakes and streams in a landscape perspective: the importance of material processing on spatial patterns and temporal coherence. Freshwater Biology 43: 477-497.

Langner CL, Hendrix PF. 1982. Evaluation of a persulfate digestion method for particulate nitrogen and phosphorus. Water Resources Research 16: $1451-1454$.

Lewis J. 1991. An improved bedload sampler. In Procedings of the 5th Federal Interagency Sedimentation Conference; 6.1-6.8.

Lewis WJ. 2002. Yield of nitrogen from minimally disturbed watersheds of the United States. Biogeochemistry 57-58: 375-385. 
Lewis WMJ, Melack JM, McDowell WH, McClain M, Richey JE. 1999. Nitrogen yields from undisturbed watersheds in the Americas. Biogeochemistry 46: 149-162.

McNamara JP. 2000. Bankfull flow, hydraulic geometry, and river ice in a northern river. In American Water Resources Spring Specialty Conference: Water Resources in Extreme Environments, Kane DL (ed.), Anchorage, AK.

McNamara JP, Kane DL, Hinzman LD. 1997. Hydrograph separations in an Arctic watershed using mixing model and graphical techniques. Water Resources Research 33: 1707-1719.

McNamara JP, Kane DL, Hinzman LD. 1998. An analysis of streamflow hydrology in an Arctic drainage basin: a nested watershed approach. Journal of Hydrology 206: 39-57.

McNamara JP, Kane DL, Hinzman LD. 1999. An analysis of arctic channel networks using a digital elevation model. Geomorphology 29: 339-353.

Mendez J, Hinzman LD, Kane DL. 1998. Evapotranspiration from a wetland complex on the Arctic Coastal Plain of Alaska. Nordic Hydrology 29: 303-330.

Meybeck M. 1982. Carbon, nitrogen, and phosphorous transport by world rivers. American Journal of Science 282: 401-450.

Oatley JA. 2002. Ice, bedload transport, and channel morphology on the Upper Kuparuk River. Master's thesis, University of Alaska Fairbanks.

Osterkamp TE, Payne MW. 1981. Estimates of permafrost thickness from well logs in northern Alaska. Cold Regions Science and Technology 5: $13-27$.

Pellerin BA, Wollheim WM, Hopkinson CS, McDowell WH, Williams MR, Vorosmarty CJ, Daley ML. 2004. Role of wetlands and developed land use on dissolved organic nitrogen concentrations and DON/TDN in northeastern US rivers and streams. Limnology and Oceanography 49: 910-918.

Perakis SS, Hedin LO. 2002. Nitrogen loss from unpolluted South American forests mainly via dissolved organic compounds. Nature 415: 416-419.
Peterson BJ, Corliss T, Kriet K, Hobbie JE. 1992. Nitrogen and phosphorus concentrations and export for the Upper Kuparuk River on the North Slope of Alaska in 1980. Hydrobiologia 240: 61-69.

Quinton WL, Pomeroy JW. 2006. Transformation of runoff chemistry in the arctic tundra, Northwest Territories, Canada. Hydrological Processes 20: 2901-2919.

Rovansek RJ, Hinzman LD, Kane DL. 1996. Hydrology of a tundra wetland complex on the Alaskan Arctic Coastal Plain. Arctic and Alpine Research 28: 311-317.

Satoru H, McCalley C, Koba K, Giblin AE, Weiss MS, Gettel GM, Shaver GR. 2006. Nitrogen fixation in surface soils and vegetation in an arctic tundra watershed: a key source of atmospheric nitrogen. Arctic, Antarctic, and Alpine Research 38: 363-372.

Sauer VB, Meyer RW. 1992. Determination of error in individual discharge measurements. US Geological Survey Open-File Report 92-144.

Serreze MC, Walsh JE, Chapin III FS, Osterkamp T, Dyurgerov M, Romanovsky V, Morison J, Zhang T, Barry RG. 2000. Observational evidence of recent change in the northern high latitude environment. Climatic Change 46: 159-207.

Stieglitz M, Shaman J, McNamara J, Engel V, Shanley J, Kling GW. 2003. An approach to understanding hydrologic connectivity on the hillslope and the implications for nutrient transport. Global Biogeochemical Cycles 17: 1105. DOI: 10·1029/2003GB002041.

Stumm W, Morgan JJ. 1981. Aquatic Chemistry. Wiley: New York

Walker MD, Walker DA, Everett KR. 1989. Wetland Soils and Vegetation, Arctic Foothills, Alaska. US Department of the Interior.

Willett VB, Reynolds BA, Stevens PA, Ormerod SJ, Jones DL. 2004. Dissolved organic nitrogen regulation in freshwaters Journal of Environmental Quality 33: 201-209.

Williams MW, Bales RC, Melack J, Brown A. 1995. Fluxes and transformations of nitrogen in a high-elevation catchment, Sierra Nevada. Biogeochemistry 28: 1-31. 